\title{
Richelieu in Marrano Garb: Conversos as Agents of the French Confessional Model, c. 1640
}

\author{
Claude B. Stuczynski
}

\section{1 French Confessional Experience through Converso Lenses}

During a visit to his native city of Bragança in northeastern Portugal, the converso Baltazar Fernandes informed his friends and relatives that: "In France there is no Inquisition, and men live according to the Law as they wish, because there is no justice which constrains them; and it will be a good thing if everybody will go there."1 Fernandes was right. Ever since the Inquisition of Coimbra began to systematically investigate the religious behavior of Bragança's New Christian population, particularly after 1585 , local conversos had lived with a growing sense of besiegement and suffocation. This led many of them, including Fernandes, to leave the city for safer places such as France, even if Judaism had been officially forbidden there since the medieval expulsions of the Jews. ${ }^{2}$ In fact, from the sixteenth century onward, France was a major spot for converso immigration, whether as a temporary sojourn or as a final destination. During the seventeenth century, it was one of the most attractive Sephardic diasporas for New Christian Judaizers, skeptics, and even for converso committed Catholics. ${ }^{3}$ On the one hand, the geographical contiguity of France to Spain

1 "Baltesar Frz. q avia pouco que viera de França lhes dise a todos como em França não avia Inquisiçam e os homes viviam na lei que queriam p q não avia justiça que os constragese e qo bom era irem se pera laa todos." Arquivos Nacionais/Torre do Tombo, Inquisição de Coimbra, processo n. 9269 , fols. $4 \mathrm{v}-5$ r.

2 William Chester Jordan, The French Monarchy and the Jews: From Philip Augustus to the Last Capetians (Philadelphia: Pennsylvania University Press, 1989), 214; Béatrice Leroy, ed., Les édits d'expulsion des juifs; 1394, 1492, 1496, 1501 (Biarritz: Atlantica, 1998); Gilbert Dahan and Élie Nicolas, eds., L'expulsion des Juifs de France, 1394 (Paris: Cerf, 2004); Céline Balasse, 1306. L'expulsion des juifs du royaume de France (Brussels: de Boeck, 2008).

3 Gérard Nahon, "The Sephardim of France," in The Sephardi Heritage; Essays on the History and Cultural Contribution of the Jews of Spain and Portugal, ed. R.D. Barnett and W.M. Schwab (Grendon, Northamptonshire: Gibraltar Books, 1989), 2: 46-74; idem, "From New Christians to the Portuguese Jewish Nation in France," in Moreshet Sepharad; The Sephardi Legacy, ed. Haim Beinart, 2 vols. (Jerusalem: Magnes Press and The Hebrew University, 1992), 2: 336-64; Anne Zink, "Une niche juridique: l'installation des Juifs à Saint-Esprit-lès-Bayonne au XVII

(C) CLAUDE B. STUCZYNSKI, 2019 | DOI:10.1163/9789004392489_005

This is an open access chapter distributed under the terms of the prevailing CC-BY-NC License at the time of publication. 
and Portugal, as well as its strategic position between southern and northern Europe bordering the Atlantic, offered unique economic and networking advantages for converso merchants, smugglers, entrepreneurs, and other travelers and adventurers. ${ }^{4}$ Especially in the seventeenth century, when it emerged as a contesting power to hegemonic Habsburg Spain, France became an appealing pole of attraction. Nonetheless, for mostly economic-mercantile reasons, from $155^{\circ}$ on, Portuguese New Christians were legally permitted to live in southwestern France as a group of merchants protected by the Crown. ${ }^{5}$ No wonder if during an inquisitorial interrogation, another late sixteenth-century Bragança converso, Martim Rodrigues, nicknamed "o Ciabrés," confessed that when he was living with his family in Saint-Jean-de-Luz: "they praised God for dwelling in a land where they could live freely according to the Law of Moses, without fearing the thieves of the Portuguese Inquisitions." ${ }^{\text {F }}$ From other inquisitorial files and historical sources, we learn that in these geographical spaces, New Christian Judaizers could practice at ease their "Marrano" traditions without being molested by any local Inquisition, as in their motherland. ${ }^{7}$ This enabled some of them, like Francisco Mendes, to meet for the first time: "a Jewish rabbi who came there to convert and teach them the belief of the Law of Moses."

siècle," Annales - Histoire, Sciences Sociales 49 (1994): 639-69; idem, "Bayonne arrivées et départs au XVII e siècle," in 1492, L'expulsion des Juifs d'Espagne, ed. Roland Goetschel (Paris: Maisonneuve et Larose, 1996), 37-47.

4 Nicolás Broens, Monarquía y capital mercantil: Felipe IV y las redes comerciales portuguesas (1627-1635) (Madrid: Ediciones de la Universidad Autónoma de Madrid, 1989); Bernardo J. López Belinchón, 'Sacar la sustancia al reino,' Comercio, contrabando y conversos portugueses, 1621-1640," Hispania 61 (2001): 1017-50.

5 Gérard Nahon, Les 'nations'Juives portugaises du sud-ouest de la France (1684-1791). Documents (Paris: Fundação Calouste Gulbenkian-Centro Cultural Português, 1981), 21-27. Cf. Brigitte Bedos-Rezak, "Tolérance et raison d'État: le problème Juif," in L'Etat baroque. Textes réunis sous la direction d'Henry Méchoulan, étude préliminaire d'Emmanuel Le Roy Ladurie, préface de André Robinet (Paris: Librairie philosophique J. Vrin, 1985), 243-87.

6 “[...] [D]arem graças a Deos de se verem em terra onde livremte. podiam viver na sua lei de Moises sem temor dos ladrões das Inquisições de Portugal." Arquivos Nacionais/Torre do Tombo, Inquisição de Coimbra, processo n. 6602, fols. 8r-v.

7 Claude B. Stuczynski, A "Marrano Religion"? The Religious Behavior of the New Christians of Bragança Convicted by the Coimbra Inquisition in the Sixteenth Century (1541-1605), 2 vols. (Ramat-Gan: Bar-Ilan University, 2005), chap. 5; Gérard Nahon, "Le modèle français du marranisme: perspectives nouvelles," in Inquisição; ensaios sobre mentalidade, heresias e arte, ed. Anita Novinsky and Maria Luiza Tucci Carneiro (Rio de Janeiro: Expressão e Cultura, 1992), 227-65; idem, "D'un singulier désir à la Loi du Dieu d'Israël: les nouveaux-chrétiens portugais en France XVI ${ }^{\mathrm{e}}-\mathrm{XVIII}$ e siècles," Arquivos do Centro Cultural Calouste Gulbenkian 48 (2004): $73^{-102 .}$

8 "[...] q quando for a acompanhar a seu pai e a sua madrasta que fugiram pera França estando todos iaa no ditto Reino de França viera a ter com eles hum judeu rabino pera os converter 
He was taking part in a gradual process of rabbinic indoctrination which ultimately led to an official acknowledgement of open Portuguese Jewish communities in the eighteenth century. ${ }^{9}$

Late sixteenth-century Bragança conversos seemed to believe that God blessed those who left inquisitorial Lusitania for a Jewish permissive Gallia. And when Isabel Rodrigues and Luis Nunes happened to meet Manuel Fernandes in Bragança, after he was smuggled into the city bringing money and letters from relatives and siblings living on the other side of the Pyrenees, "they said [to] him that these were good relatives and since they lived in the good Law, God helped them."10 This episode echoed a widespread converso equation between Judaism and wealth, which aimed to demonstrate that the children of Israel were still God's most cherished people, despite religious coercion and inquisitorial persecution. ${ }^{11}$ If this rationale relied on the premise that the better the Law of Moses is fulfilled the more its followers will be rewarded by Providence, it appears that France was perceived as a paradise for enrichment, due to the religious freedom enjoyed by the converso immigrants and their offspring. At the same time, the inquisitorial data clearly indicates that Bragança's New Christians were aware of the limitations of such liberty. Thus, Belchior Álvares, who had visited a group of New Christians established in Saint-Esprit-lès-Bayonne, remembered that even if nobody there feared denunciation, they still concealed their Judaic proclivities from their neighbors: "keeping them hidden from the French."12 According to another Bragança New Christian named Diogo Guerreiro, what characterized the French religious landscape he personally knew was that everyone, whether converso Judaizers

e ensinar a crença da lei de Moises." Arquivos Nacionais/Torre do Tombo, Inquisição de Coimbra, processo n. 484 .

9 Carsten L. Wilke, "Un judaïsme clandestin dans la France du XVII e siècle: un rite au rythme de l'imprimerie," in Transmission et passages en monde juif, ed. Esther Benbassa (Paris: Publisud, 1997), 281-311. Cf. Gérard Nahon, "Prospective des 'Portugais' du sudouest de la France à la veille de la Révolution," in Politique et religion dans le judaïsme moderne, des communautés à l'émancipation, ed. Daniel Tollet (Paris: Presses de l'Université de Paris-Sorbonne, 1987), 85-104.

10 "[...] que aqueles erão bons parentes e que assi como viviam em boa lei, assi os ajudava Deos [...]." Arquivos Nacionais/Torre do Tombo, Inquisição de Coimbra, processo n. 8798, fols. $28 \mathrm{r}-\mathrm{v}$.

11 Claude B. Stuczynski, "Judaïcité et richesse dans l'apologétique des Conversos portugais: un argument contre-culturel," Atalaya 14 (2014): http://atalaya.revues.org/1295.

12 "[...] posto q se escondião dos franceses." Arquivos Nacionais/Torre do Tombo, Inquisiçãa de Coimbra, processo n. 7934, fol. $5^{2 v}$. 
or Protestant Huguenots, could live side by side with their Catholics neighbors, provided their religious practices were kept indoors: "portas adentro."13

These few examples, taken from more than five hundred trials of the Coimbra Inquisition against late-sixteenth- and early-seventeenth-century New Christians living in Bragança I studied years ago, of a city called by Israël Salvator Révah "métropole de crypto-judaïsme" for the impressive numbers of convicted Judaizers by the Holy Office, addresses an idealized portrait of Iberian conversos living under the early modern French confessional umbrella. ${ }^{14}$ In these sources, one finds no mention of those numerous moments of tension, hostility, and incertitude experienced by converso emigres, including local expulsions and circumscribed violence. ${ }^{15}$ Moreover, there is no word concerning the brutal persecutions and bloody massacres suffered by the Huguenot minority during the wars of religion, such as around the St. Bartholomew's Day of 1572. At the same time, nothing is said regarding the rights granted by the French monarchy to the Huguenot minority in the Edict of Nantes of 1598, which included freedom of public worship in specific geographic areas, as well as safe havens, which were military strongholds, such as La Rochelle. ${ }^{16}$ In the above-mentioned inquisitorial files, there is no echo of the tensions found in rabbinic and Sephardic communal sources between those converso emigres who were satisfied with the minimalistic, concealed, and informal forms of Judaism they could practice in France, and those exconverso "New Jews" who, living in official Sephardic communities, argued that the Law of Moses is inherently maximalist and could only be properly practiced in "lands of Judaism" (terras de Judesmo) such as Amsterdam. ${ }^{17}$ Moreover, New Christians who continued to live in France as committed Catholics, as

13 Arquivos Nacionais/Torre do Tombo, Inquisição de Coimbra, processo n. 880o, fol. 39r.

14 Israël Salvator Révah, "Aux origines de la rupture spinozienne: nouvel examen des origines du déroulement et des consequences de l'affaire Spinoza-Prado-Ribera," Annuaire du Collège de France 71 (1971): 584. Stuczynski, A "Marrano Religion"? Cf. Elvira Cunha de Azevedo Mea, A Inquisição de Coimbra no século XVI: a Instituição, os Homens e a Sociedade (Porto: Fundação Engenheiro António de Almeida, 1997), passim.

15 E.g., Jacques Blamont, Le lion et le moucheron. Histoire des Marranes de Toulouse (Paris: Odile Jacob, 2000).

16 Bernard Cottret, 1598, L'Édit de Nantes (Paris: Perrin, 1997); Bernard Barbiche, "L'Édit de Nantes et son enregistrement: génèse et publication d'une loi royale," in Paix de armes, paix des âmes, ed. Paul Mironneau and Isabelle Pébay-Clottes (Paris: Imprimerie nationale, 2000), 251-26; Christian Jouhaud, "Religion and politics in France during the period of the Edict of Nantes," in Religious Differences in France: Past and Present, ed. Kathleen P. Long (Kirksville, MO: Truman State University Press, 2006), 73-90.

17 Yosef Kaplan, "Wayward New Christians and Stubborn New Jews: The Shaping of a Jewish Identity," Jewish History 8 (1994): 27-41. 
well as those who discovered outside the Iberian Peninsula that they were not only "potential Jews" but also "potential Catholics" inculcated with IberianCatholic values, left no written traces in the vast inquisitorial data I consulted. ${ }^{18}$ Beyond an epistemic explanation for these omissions related to the inquisitorial-bureaucratic notarial writing genre and the juridical-procedural method of rhetorical bargaining that took place between the inquisitor and the inquired, I argue that such incomplete and distorted ways of perceiving the early modern French confessional model reflect two pervasive historical realities. On the broader level, it echoes the intermediary stages between the violent wars of religion in the sixteenth century and the imposition of "enlightened" confessional policies in eighteenth-century Western and Central Europe. At such times, different confessional communities beyond the Alps and the Pyrenees managed to negotiate a certain modus vivendi. ${ }^{19}$ The result was the relatively peaceful, albeit fragile religious coexistence, which late-sixteenth- and earlyseventeenth-century Bragança conversos met in southwestern France, a region densely populated by a vibrant Huguenot community. ${ }^{20}$ More specifically, it is worth remembering that for Portuguese New Christians, whether cryptoJewish or not, Gallicanism was an extremely appealing alternative to Iberian Catholicism. I refer here neither only to the special privileges New Christians enjoyed in early modern France as a protected group of merchants and then as members of a Portuguese "nation," from the "lettres patentes" issued in $155^{\circ}$ by Henri II and expanded by subsequent monarchs nor to the fact that men of immense power, such as the minister of King Louis XIII, Cardinal Richelieu, welcomed the conversos, supported the New Christian Judaizer sub-group, and employed them as an economic, political, and logistical means to weaken the Spanish-Habsburg hegemony. ${ }^{21}$ No wonder if from 1627 Rouen, the exiled

18 Natalia Muchnik, "Du judaïsme au catholicisme: les aléas de la foi au XVIIe siècle," Revue Historique 623 (2002): 571-6o9; idem, "Du catholicisme des judéoconvers: Rouen, 1633," XVII e siècle 231 (2006): 321-43; David L. Graizbord, Souls in Dispute Converso Identities in Iberia and the Jewish Diaspora, 1580-1700 (Philadelphia: Pennsylvania University Press, 2004).

19 Benjamin J. Kaplan, Divided by Faith: Religious Conflict and the Practice of Toleration in Early Modern Europe (Cambridge, MA: Belknap Press of Harvard, 2007). Cf. Keith T. Luria, Sacred Boundaries. Religious Co-existence and Conflict in Early Modern France (Washington, DC: The Catholic University of America Press, 2005).

20 Philip Benedict, "The Huguenot Population of France, 1600-1685: The Demographic Fate and Customs of a Religious Minority," Transactions of the American Philosophical Society 81 (1991): 1-164; Philippe Chareyre, "Démographie et minorités protestantes," Bulletin de la Société de l'Histoire du Protestantisme Français 148 (2002): 867-89.

21 Israël Salvator Révah, Le Cardinal de Richelieu et la restauration du Portugal (Lisbon: Institut Français du Portugal, 1950); Françoise Hildesheimer, "Une créature de Richelieu: 
Portuguese converso writer João Pinto Delgado dedicated his "Poema de la Reina Ester" along with other biblical works to Cardinal Richelieu, for protecting "wanderers" (peregrinos) like himself. Pinto Delgado's noble and generous portrait of Louis XIII's minister was close to the image of Ahasuerus's most devoted minister, Mordecai, in times when the figure of Haman was evoked in political discourses to criticize the employment of ministers and favorites by European princes. ${ }^{22}$ Rather, in this paper, I aim to show that for many early modern conversos and pro-converso elements, the French-Gallican confessional model was an attractive, alternative way of combining the political and the religious domains in order to solve the persistent "converso problem" in the Iberian Peninsula, without altering the Catholic and corporate character of the society. This phenomenon of converso and pro-converso political agency, which I call "Richelieu in Marrano garb," became tangible at a very specific historical moment: between Portugal's dynastic independence from the Spanish Habsburgs on 1 December 1640 and the Peace of the Pyrenees of 7 November 1659, which ended warfare between France and Spain. More precisely, "Richelieu in Marrano garb" crystallized when the newly "restored" Portuguese dynasty of Braganza under John IV desperately sought diplomatic support and military assistance from France to avoid Spanish-Habsburg retaliation. ${ }^{23}$ Under these historical circumstances, two conversos living in France, the Portuguese diplomat Manuel Fernandes Vila Real (1608-1652) and the Spanish-born and partly converso writer Antonio Enríquez Gómez (160o-1661), were propelled to join that ephemeral Portuguese-French alliance by offering the Gallican confessional model to meet Portugal's pressing needs. Both writers have been exhaustively studied by leading scholars.

Alphonse Lopez, le 'Seigneur Hebreo', in Les Juifs au regard de l'histoire. Mélanges en l'honneur de Bernhard Blumenkranz, ed. Gilbert Dahan (Paris: Picard, 1985), 293-99. João Pinto Delgado, Poema de la Reina Ester, Lamentaciones del Propheta Ieremias, Historia de Rut, y varias poesias (Rouen: chez David du Petit Val, imprimeur ordinaire du Roy, 1627), introduction; Israël Salvator Révah, "Autobiographie d'un marrane. Édition partielle d'un manuscript de João (Moseh) Pinto Delgado," Révue des Études Juives 119 (1961): 41-13o, esp. 115-16. Cf. John H. Elliott and Laurence W.B. Brockliss, eds., The World of the Favorite (New Haven and London: Yale University Press, 1999), passim.

23 João Franco Barreto, Relação da embaixada a França em 1641, por João Franco Barreto. Reimpressa com noticias e documentos elucidativos por Carlos Roma Du Bocage e Edgar Prestage (Coimbra: Imprensa da Universidade, 1918); Edgar Prestage, The Diplomatic Relations of Portugal with France, England and Holland from 1640 to 1668 (Watford: Voss \& Michael, 1925); Moses Bensabat Amzalak, As relações diplomaticas entre Portugal e a França no reinado de D. João IV (1640-1656): documentos e notas (Lisbon, n.p. 1934); Eduardo Brazão, A diplomacia portuguesa nos séculos XVII e XVIII (Lisbon: Editorial Resistência, 1980). 
Initially, the affinities of Vila Real and Enríquez Gómez were explored vis-àvis their support for the Franco-Portuguese alliance, ${ }^{24}$ their common opposition against the Iberian Inquisitions, ${ }^{25}$ and the more controversial question of their crypto-Jewish allegiances. ${ }^{26}$ More recently, they have been investigated through the prism of hybridity. Enríquez Gómez is now portrayed as a halfconverso-Castilian-pro-Portuguese-Francophile-libertine, whereas Vila Real

24 Constance H. Rose, "Portuguese Diplomacy Plays a Role in the Printing of Some Peninsular Works in Rouen in the Seventeenth Century," Archivos do Centro Cultural Português 9 (1975): 523-41; Michèle Gendreau-Massaloux and Constance H. Rose, "António Enríquez Gómez et Manuel Fernandes de Villareal: deux destins parallèles, une vision politique commune," Revue des études juives 136 (1977): 368-87; Luís Reis Torgal, Ideologia política e teoria do Estado na Restauração: contributo para o seu estudo (Coimbra: Biblioteca Geral da Universidade de Coimbra, 1981-1982), 1: 412-19; 2: 32-36, 213-23; Iva Delgado, "Manuel Fernandes Vila Real, polemista da Restauração," Revista da Biblioteca Nacional 3 (1983): 27-46; António Borges Coelho, "Manuel Fernandes Vila Real no discurso político dos primeiros anos da Restauração," in A união ibérica e o mundo atlântico, ed. Maria da Graça A. Mateus Ventura (Lisbon: Colibri, 1997), 285-306; Henry Méchoulan, "Manuel Fernandes Vila Real, un marrane en politique," Nova Renascença 67 (1998): 305-16; João Pedro da Silva Gomes, "O ‘Epítome genealógico' de M. Fernandes Vila Real e a 'Política angélica' de Antonio Enríquez Gómez: o pensamento político de dois cristãos-novos na década de 1640" (master's thesis, Universidade Nova de Lisboa, 2008); Jaime Galbarro García, "Manuel Fernández Villareal y la propaganda de la 'nação' Portuguesa," Versants 60 (2013): 131-42; idem, El 'Triumpho lusitano' de Antonio Enríquez Gómez (Seville: Editoral Universidad de Sevilla, 2015).

25 Israël Salvator Révah, "Manuel Fernandes Vilareal, adversaire et victime de l'Inquisition portugaise," Ibérida 1 (1959-1960): 33-54, 181-207; Maximiliaan Paul Adriaan Maria Kerkhof, "La 'Ynquisiçion de Luzifer y uisita de todos los diablos.' Texto desconocido de Antonio Enríquez Gómez: edición de unos fragmentos," Sefarad 38 (1978): 319-31; Michael McGaha, "Divine Absolutism vs. Angelical Constitutionalism: The Political Theories of Quevedo and Enríquez Gómez," in Studies in Honor of Bruce W. Wardropper, ed. Dian Fox, Harry Sieber and Robert Ter Horst (Newark, DE: Juan de la Cuesta, 1989), 181-92; Nechama Kramer-Hellinx, Antonio Enríquez Gómez: literatura y sociedad en El siglo pitagórico y Vida de don Gregorio Guadaña (New York: Peter Lang, 1992); Constance H. Rose, "Dios hará inquisición de vuestros juicios': Antonio Enríquez Gómez' Search for Justice," Sefarad 61 (2001): 169-86.

26 Timothy Oelman, "The Religious Views of Antonio Enríquez Gómez: Profile of a Marrano," Bulletin of Hispanic Studies 41 (1983): 201-9; Herman P. Salomon, "Nova luz sobre a condenação à fogueira a Manuel Fernandes Vila Real (1. XII. 1652)," in Inquisição, ed. Maria Helena Carvalho dos Santos, 3 vols. (Lisbon: Universitária Editora, 1989), 2: 765-73; Constance H. Rose, "Fiel a la antigua ley: 'La política angélica' de Enríquez Gómez," in Antonio Enríquez Gómez, ed. Gema Ortega (Cuenca: Diputación de Cuenca, departamento de cultura, 1996), 105-10; Israël Salvator Révah, Antonio Enríquez Gómez, un écrivain marrane (v. 16oo-1663), ed. Carsten L. Wilke (Paris: Chandeigne, 2003); Matthew Warshawsky, "A Spanish Converso's Quest for Justice: The Life and Dream Fiction of Antonio Enriquez Gómez," Shofar 23 (2005): 1-24; Herman Prins Salomon, "Was Antonio Enríquez Gómez (1600-1663) a Crypto-Jew?" Bulletin of Hispanic Studies 88 (2011): 397-421. 
is viewed as the embodiment of interstitiality, the converso as "productive intermediary" between different religions, cultures, social classes, and family networks. ${ }^{27}$ In this article, I seek to show that beyond these circumstantial and biographical considerations, conversos and their allies longed to impart to the Iberian Peninsula two intertwined traits they found in early modern France: a dose of freedom of conscience and a more assertive way to govern a centrifugal corporate society. While I endorse Joseph Bergin's dynamic and variegated portrait of early modern French politics and religion, I argue that seen from the Iberian Peninsula, the question of whether the French confessional model evolved from a "church in the state" to "the state in the church" is not an "otiose matter." 28 Whereas the latter option countered the political and religious foundations of the early modern Iberian Peninsula, the former was a more feasible way to incorporate the French confessional model into Iberian society, without undermining its traditional basis. Precisely for this reason, those who promoted "Richelieu in Marrano garb" stressed their commitment to the first option, while accusing the Spanish Habsburgs and the Portuguese Inquisition of employing the latter in a disguised and hypocritical manner.

\section{2 The Public versus the Private}

But why the French confessional model? More than in any other early modern Catholic country, in France there existed a clear distinction between religious crimes committed publicly, in foro externo, and those committed discreetly, in foro interno. ${ }^{29}$ According to a "caesaro-papistic" interpretation of the verse: "Render therefore unto Caesar the things which are Caesar's and unto God the things that are God's" (Matthew 22:20-22), in early modern France the

27 Carsten L. Wilke, Jüdisch-Christliches Doppelleben im Barock (Frankfurt: Peter Lang, 1994); Valentina Nider, "La doppia simulazione di Enríquez Gómez: 'La culpa del primer peregrino'," in Alle radici dell'Europa. Mori, guide e zingari del mediterraneo occidentale, vol. 2, secoli XVII-XIX, ed. Felice Gambin (Florence: Seid, 2010), 195-210; J. Ignacio Díez and Carsten Wilke, eds., Antonio Enríquez Gómez. Un poeta entre santos y judaizantes (Kassel: Eva Reichenberger, 2015); Carsten L. Wilke, "Manuel Fernandes Vila Real at the Portuguese Embassy in Paris, 1644-1649: New Documents and Insights," Journal of Levantine Studies 6 (2016): 153-76.

28 Joseph Bergin, The Politics of Religion in Early Modern France (New Haven and London: Yale University Press, 2014), 299-307.

29 According to Paolo Prodi, such dualistic way of conceiving the foro interno as the domain left by the public foro externo, was a "modern" idea which contributed to the separation between juridical and moral norms (Paolo Prodi, Una storia della giustizia. Dal pluralismo dei fori al moderno dualismo tra coscienza e diritto [Bologna: Il Mulino, 2000], 332-89). 
monarch was perceived as the ultimate instance to judge crimes committed in foro externo, including heresy. Unreserved heresy, after all, was a "scandal" (scandale) openly committed against the political order and thus was considered after the Roman law an act of treason against the king and the state ("crimen lesae maiestatis"). In 1540, Francis I established an extraordinary court of justice to deal with such public "scandals," called "the Burning Chamber" (la Chambre ardente). The Burning Chamber was attached by the king to the Parliament in collaboration with the Faculty of Theology of Paris. The methods and outcomes of this institution were harsher than the more "pedagogic" and confessional-reconciling aims of the Inquisition. ${ }^{30}$ At the same time, only a limited number of individuals was prosecuted by the Burning Chamber, especially after the Edict of Nantes, which was an exceptional political compromise made by the French sovereign with his Huguenot "heretic" subjects to obtain civil appeasement. Crimes perpetrated discreetly in foro interno traditionally belonged to the sphere of conscience (foro conscienciae) and were considered by Christian lawyers and theologians as the domain of God and His Church. ${ }^{31}$ In inquisitorial lands, such as early modern Iberia and Italy, a priest-confessor was not able to acquit in the name of God a crime of heresy committed in foro interno, because it also deserved Church excommunication. Therefore, it had first to be absolved by the confessional-penitential ecclesiastical instance for heretical crimes, which was the Holy Office. ${ }^{32}$ In early

$30 \quad$ Nethanël Weiss, La Chambre ardente: Étude sur la liberté de conscience en France sous François Ier et Henri II (1540-1550), suivie d'environ 500 arrêts inédits rendus par le Parlement de Paris de mai 1547 à mars 1550 (Geneva: Slatkine Reprints, 1970); Nicola Mary Southerland, "Was there an Inquisition in Reformation France?" in idem, Princes, Politics, and Religion, 1547-1589 (London: The Hambledon Press, 1984), 13-29; William Monter, Judging the French Reformation: Heresy Trials by Sixteenth-Century Parliaments (Cambridge, MA: Harvard University Press, 1999); Alain Tallon, "Inquisition romaine et monarchie française au XVI ̀̀ siècle," in Inquisition et pouvoir, ed. Gabriel Audisio (Aix-enProvence: Publications de l'Université de Provence, 2004), 311-24.

31 E.g., "In foro conscientiae causa agitur inter hominem et Deum; in foro autem exterioris iudicii causa agitur hominis ad hominem; et ideo absolutionis vel ligatio quae unum hominem obligat quo ad Deum tantum, pertinent ad forum poenitentiae; sed illa quae hominem obligat in comparationes alios homines, ad forum publicum exterioris iudicii pertinent." Thomas Aquinas, Sententiae, IV, d.18, q.3, a. 2. An effort to distinguish the juridical category of foro interno from the moral foro conscienciae is to be found in Velasio de Paolis, "Natura e funzione del foro interno," in Investigationes Theologico-canonicae, ed. U. Navarrete (Rome: Università Gregoriana Editrice, 1978), 115-42. Cf. Stephan Kuttner, "Ecclesia de occultis non iudicat. Problemata ex doctrina poenali decretistarum et decretalistarum a Gratiano usque ad Gregorium PP. IX," in Acta congressus iuridici internationalis, Romae 1934 (Rome: Libr. Pont. Institutis Utriusque Iuris, 1936), 3: 225-46.

32 Prodi, Una storia della giustizia, 92-97. These procedures did not exhaust the uncertainties, tensions, and negotiations in inquisitorial lands between hidden "heretic" crimes 
modern France, however, such secret misdeeds were basically absolved by the traditional spiritual guardian and shepherd of the Christian flock, namely, the bishop. Following a failed attempt in 1550 to introduce in France an inquisition after the Iberian model by Henry II, the Edict of Chateaubriand of ${ }^{1551}$ stressed that every punishable crime should fall under the jurisdiction of the French Parliament. According to Ellena Brambilla, the consequence was that heresies committed in foro interno ceased to be prosecuted by the bishops, because they lost any effective means of dissuasion. ${ }^{33}$ These measures of juridical secularization and monopolization by the merging state were often coupled with an elaboration upon the traditional Capetian idea that the French monarch was divinely chosen by God. Having a sacral dimension, French monarchs could claim secular rights or regalia concerning the Church and appeared as the most committed supporters of the Gallican bishopric autonomies vis-àvis the Pope. ${ }^{34}$ Early modern French state-building thus combined political centralistic inclinations, religious autonomy from the Pope, and a certain freedom of conscience, while publicly remaining Catholic. These traits enabled Portuguese conversos established in France to live indoors unmolested, provided they behaved as Catholics in foro externo by attending church, being baptized and buried as Catholics, and avoiding public "scandals" (e.g., public acts of Judaism). From the first "lettres patentes" of naturalization of 1550 , New Christian merchants were considered by Henry II as his "good and loyal subjects" (bons et loyaulx subiectz), deserving the same rights and privileges enjoyed by their French neighbors ("de tous et chacuns les privileges, franchises et libertés dont ont accoustumé joy et user nos propres subiects et mesmes habitans des villes où se seront retirez lesdits Portugais"), including in criminal domains. ${ }^{35}$ In the royal privilege of 1574 issued by Henry III on behalf of the New Christians living in Bordeaux, it was stated that conversos should live in the city peacefully in full liberty: "without having their lives or other aspects

committed "in foro conscienciae," the role of confessor-priest and that of the Holy Office. See Adriano Prosperi, Tribunali della coscienza: Inquisitori, confessori, missionari (Turin: Einaudi, 1996); Stefania Tutino, Shadows of Doubt: Language and Truth in Post-Reformation Catholic Culture (New York: Oxford University Press, 2014), esp. 12-34.

33 Ellena Brambilla, Alle origini del Sant'Uffizio. Penitenza, confessione e giustizia spirituale dal medioevo al XVI secolo (Bologne: Il Mulino, 200o), esp. 411-36; idem, La giustizia intollerante. Inquisizione e tribunali confessionali in Europa (secoli IV-XVIII) (Rome: Carocci, 2006), 169-72.

34 Jonathan Powis, "Gallican Liberties and the Politics of Later Sixteenth-Century France," The Historical Journal 26 (1983): 515-30.

35 Nahon, Les 'nations' Juives portugaises du sud-ouest de la France (1684-1791). Documents, 23-24. 
inquired into" (sans estre recherchés en leur vie ni autrement). ${ }^{36}$ I will argue that this explicit mention must be understood as a reaction to some "calumnious denunciations" mentioned in the document, which aimed to expel the conversos from the city on the basis of crypto-Jewish behavior. However, like the failed attempt of Marie of Medicis in 1615 to expel the "Jews" and "disguised Jews" from France and the sui generis "auto-da-fe" held against conversos in Toulouse in $1685,{ }^{37}$ these exceptional initiatives stemmed from efforts to ban discreet forms of "Judaism" from the unpunishable domain of the foro interno after the Iberian confessional model. In this respect, freedom of conscience in early modern France was open to different interpretations: whether in lato sensu, as internal religious behavior, or in stricto sensu, as mere freedom of opinion and belief. However, such freedom had little to do with broader forms of freedom of conscience practiced by ex-converso "New Jews" in "terras de judesmo," such as in Amsterdam or Livorno, in which they could legally live as practicing Jews, as well as regarding the circumscribed religious liberties exceptionally conceded by French monarchs to the Huguenot minority.38

This French or Gallican separation of the public from the private domain was promoted by Manuel Fernandes Vila Real, in his del eminentíssimo cardenal Duque de Richelieu (1641) and António Enríquez Gómez, especially in his Política angélica (1647). ${ }^{39}$

36 Ibid., 30. See a confirmation in the "lettres patentes" of 1656 by Louis XIV: "[...] ni être recherchez de façon quelconque en leur vie, ou autrement inquiétez ou molestez en leur personnes \& biens, en quelque manière que ce fût." Ibid., 33 .

37 Zosa Szajkowski, "An Auto-da-Fé against the Jews of Toulouse in 1685," The Jewish Quarterly Review 49 (1959): 278-81; Gérard Nahon, "Exception française et réponse au modèle ibérique: Marie de Médicis et la 'Déclaration qui expulse les Juifs du Royaume de France' du 23 avril 1615," in L'expulsion des Juifs de Provence et de l'Europe méditerranéenne (XV $-X V I^{e}$ siècles); exils et conversions, ed. Danièle Iancu-Agou (Paris and Leuven: Peeters, 2005), 111-28.

38 Lucia Frattarelli Fischer, Vivere fuori dal ghetto. Ebrei a Pisa e Livorno (secolo XVI$X V I I I)$ (Turin: Silvio Zamorani Editore, 2008); Miriam Bodian, "The Portuguese Jews in Amsterdam and the Language of Liberty," Journal of Levantine Studies 6 (2016): 313-32. In the case of Amsterdam, religious liberty was limited and circumscribed to the community space of the synagogue and home (Cf. Yosef Kaplan, "Between Calvinists and Jews in Seventeenth-Century Amsterdam," in Conflict and Religious Conversation in Latin Christendom: Studies in Honor of Ora Limor, ed. Ram Ben-Shalom and Israel J. Yuval [Brepols: Turnhout, 2014], 289-9o).

39 Manuel Fernandes Vilareal, Epítome genealógico del eminentissimo Cardenal Duque de Richelieu y discursos politicos sobre algunas acciones de su vida, Pamplona: Iuan Antonio Berdun, 1641 (hereafter, Epitome genealógico). I also consulted the modern Portuguese edition of António Borges Coelho, Epítome Genealógico do Eminetissimo Cardeal Duque de Richelieu e Discursos Políticos sobre Algumas Acçõesa da Sua Vida (Lisbon: Caminho: 2005). Concerning Antonio Enríquez Gómez, his political views and criticism of the 
Scholarship has awarded these tracts a certain amount of comparative attention. ${ }^{40}$ For our purposes, I will simply mention that both were presented as tributes to French authorities. The Epitome genealógico was dedicated to Cardinal Richelieu, while the first part of the Política angélica was offered to Jean Louis Faucon, president of Normandy's Parliament and counselor of Louis XIII. ${ }^{41}$ Vila Real's laudatory biography of Richelieu, later known as El político cristianisimo (1642), almost coincided with the death of Louis XIII's minister on 4 December 1642. Perhaps for this reason, it became a tool of French propaganda and was translated into French and Italian. In glossing Richelieu's life and deeds, Vila Real praised the way he combined Catholic values with successful politics. And when he was imprisoned by the Inquisition of Lisbon in 1649 on grounds of crypto-Judaism, Vila Real argued that the book was reviewed by Cardinal Mazarin and by members attached to Portugal's embassy in Paris, such as Friar Francisco de Santo Agostinho. Since he did not have any intention to harm Portugal's Holy Office, but only to praise Richelieu's Catholic policies, the Epitome genealógico is not to be seen as a heretical book. ${ }^{42}$ Enríquez Gómez's Política angélica was less concerned with Richelieu's life. Rather, it celebrated the way France promoted "angelic politics" and most particularly, it criticized Iberian "diabolic politics" epitomized by the Inquisition. According to Israël Salvator Révah, the second part was written with Iberian

Iberian Inquisitions and one of his social debased byproducts, the "malsín" appear in many of his works. In this article I will focus on both the first part of his "Política Angelica" (Antonio Enríquez Gómez, Política angélica, primera parte dividida en 5. Dialogos [Rouen: L. Maurry, 1647], hereafter, Política angélica) and the second, published by Israël Salvator Révah, "Un pamphlet contre l'Inquisition. La seconde partie de 'La política angélica' de Antonio Enríquez Gómez (Rouen, 1649)," Revue des Études Juives 121 (1962): 81-168 (hereafter, Révah, "Un pamphlet." Only occasionally I will refer to Enríquez Gómez's, Luis dado de Dios a Luis y Ana Samuel dado de Dios a Elcana y Ana [Paris: René Baudry, 1645], hereafter, Luis dado de Dios).

40 In the second poem written by Enríquez Gómez at the beginning of the "Epítome Genealógico" to celebrate Vila Real's book he said: "Dió a un epitome forma/ De aquella mente Angelica y Divina; / Y tu Pluma Política, camina/ Alinear los conceptos, que te informa." Was this a restrospective allusion to Enríquez Gómez's future claims in Política angélica?

41 Antonio Enríquez Gómez, Política Angélica, primera parte dividida en 5. Dialogos (Rouen: L. Maurry, 1647).

42 José Ramos Coelho, Manuel Fernandes Villa-Real e o seu processo na Inquisição de Lisboa (Lisbon: Empreza do Ocidente, 1894), 52-53. Cf. António Baião, Episódios dramáticos da Inquisição portuguesa (Rio de Janeiro: Álvaro Pinto Editor, 1924), 2: 364-68; Révah, "Manuel Fernandes Vilareal, adversaire et victime de l'Inquisition portugaise." 
authorities in mind, although formally dedicated to every Catholic sovereign ("dedicado a todos los Principes Christianos, Columnas de la Militante Iglesia de Roma") to suggest a more appropriate way to deal with converted subjects and heretics ("sobre el govierno, que se deve tener con los Reduzidos a la Fe Catholica, y con los que se apartaron della"), than the rigor employed in "some kingdoms" ("[d]eseando con piadoso celo dar un medio sobre el gobierno riguroso que se ejecuta en algunos Reinos sobre los delitos de religion"). ${ }^{43}$ Presented as a sort of Catholic confessional guide, the second part of the Política angélica dealt specifically with the Inquisition. It was no wonder that the book was immediately condemned in Iberia and its second part banned in France through the intervention of Portugal's ambassador in Paris, the Marquis of Niza. Vila Real informed the inquisitors that he had tried to dissuade his friend from publishing the second part, because it overtly questioned the Holy Office, an institution supported by the papacy. ${ }^{44}$ The Epitome genealógico and the Política angélica were written as Catholic tracts by two Iberian New Christians who opted for the Gallican confessional model over the Iberian. They expressed similar views, although they employed different emphases and rhetorical devices. The former glorified Richelieu's life and deeds, while making comments in the form of morals inferred from the Cardinal's actions. The latter was straightforward in its condemnation of Spain and Portugal, but much more laconic regarding Richelieu's achievements.

In the introduction of the Epitome genealógico, Vila Real explained his decision to write a biography of Louis XIII's favorite: because Richelieu's political wisdom deserved to be known by Spanish readers, until now ignored because of linguistic and political estrangement. ${ }^{45}$ Following Plutarch's biographic-didactic historiography, Vila Real portrayed the Cardinal, mostly to underscore how he successfully managed religion in France's political life. After reminding the reader of Richelieu's noble ascendancy and upbringing by stressing his virtuous personality and ecclesiastical probity, he concluded: "[s]omeone who rightly observes the divine laws, cannot err in human (laws); nor could be a bad counselor to a prince who is a good minister of God."46 Accordingly, Richelieu's political wisdom emanated from theological knowledge and pious behavior and not from aleatory savoir faire. This comment was intended to

\footnotetext{
43 Révah, "Un pamphlet," 10o. Cf. Luis Reis Torgal, "A literatura 'marrânica' e as 'edições duplas' em Antonio Henriques Gomes (160o-1663)," Biblos 55 (1979): 197-228.

44 Révah, "Un pamphlet," 93-98.

45 "Ten en tu gracia, pues te hago participe en tu lengua de lo que ignoravas, por estar en otras que no entendias, ò de aquello que no amavas, por no saber era digno de amarse" (Vila Real, Epítome genealógico, "Al Lector" n.p.). 
contrast Richelieu's successful government with the by-then failing ministry of his Spanish rival, the favorite of King Philip IV, the Count-Duke of Olivares. ${ }^{47}$ That said, only occasionally did Vila Real censure the Spanish monarch (e.g., for living idly at court hidden from his subjects) and critique Olivares (e.g., because his centralist policy of "Unión de Armas" exacerbated civil antagonism instead of support). ${ }^{48}$ For the most part, Epitome genealógico strove to celebrate Richelieu's policies as a model to be emulated. Something similar could be said regarding Enríquez Gómez, in his criticism of Iberia. In the introduction to Part One of the Política angélica, he mentioned en passant the name of Virgilio Malvezzi, the author of an acclaimed biography of Olivares: "Il ritratto del privato politico Cristiano" (1635). This work probably prompted Vila Real to write his biography of Richelieu, ${ }^{49}$ and it was one of Enríquez Gómez's possible sources of inspiration in comparing monarchs with God, ministers with angels, and a virtuous government with "angelic politics." ${ }^{50}$ However, here again Philip IV and Olivares were occasionally attacked as such. ${ }^{51}$ On a theoretical level, the Política angélica dismissed Niccoló Machiavelli for supporting cunning and fraud as a legitime political means of government, and Jean Bodin for enabling envy between the prince's ministers to avoid intrigues against the sovereign according to the unethical ("non-angelical") principle of "divide

47 Cf. John H. Elliott, Richelieu and Olivares (Cambridge: Cambridge University Press, 1991).

48 "Añadir vn Reyno, y otro Reyno, a vna Monarchia grande sin sugetar los animos, no es aumentar el dominio si no arriesgarle, es grangear enemigos ocultos, quando pudieran ser menos dañosos descubiertos. Solo deve llamarse vnion la que forman los coraçones, no la que establecen las Armas." Vila Real, Epítome genealógico, 216. Vila Real was alluding to Olivare's centralistic policy of "Unión de Armas" (cf. John H. Elliott, The Count-Duke of Olivares. The Statesman in an Age of Decline [New Haven and London: Yale University Press, 1986], 124, 244-46, 270-77).

49 "La estimacion, que los escritos de vn Moderno Politico, han merecido la opinion de muchos, despertó mi Pluma, en vna dilatada ociosidad, a la traduccion del vltimo retrato de su doctor pinsel. Pero considerando en las acciones de vn gran Ministro, el original de aquella copia, y que en el era execucion, lo que en el otro discurso, que aquel repetia lo que devia hazerse, y que este obrava lo que los otros enseñavam; mudando de intento, dexé la explicacion de agenos conceptos, para repetir los mios, o los de mis estudios en la composission deste discurso." Vila Real, Epitome genealógico, "Al Lector," n.p.

$50 \quad$ E.g., "Philonio: Pues que politica en potencia le conviene tener al Principe en el estado? Theogonio: La que tiene Dios con los Angeles" (Enríquez Gómez, Política Angélica, 17). Cf. "Sono talvolta figura di Dio con noi gli angeli; degli angeli i favoriti co' principi, di Dio i principi con gli uomini" (Virgilio Malvezzi, Il Ritrato del Privato Politico Cristiano, ed. Maria Luisa Doglio [Palermo: Sellerio editore, 1993], 35).

51 Cf. Michael D. McGaha, "Antonio Enríquez Gómez and the Count-Duke of Olivares," in Texto y espectáculo: nuevas dimensiones críticas de la "comedia," ed. Arturo Pérez-Pisonero and Ana Semidey (El Paso: University of Texas, 1990), 47-54. 
and rule."52 In spite of the efforts made by the Spanish translator of Bodin's Six Books of the Republic (1590), to disassociate the book from the bête noire of early modern political thought, Machiavelli (by stressing Bodin's personal commitment to Christian values and by removing or modifying from the original some equivocal excerpts), ${ }^{53}$ the book was included in the Spanish Index of Prohibited Books in 1612. Moreover, several Iberian writers, from Pedro de Ribadeneyra to Francisco de Quevedo, accused Bodin of being the main muse for Machiavelli's followers. ${ }^{54}$ Enríquez Gómez praised the more accepted neostoic and "Tacitian" views of Justus Lipsius as an alternative to Machiavelli and Bodin. This was mostly done without mentioning Lipsius, by quoting his elaborations on the Roman historian Publius Cornelius Tacitus. ${ }^{55}$ Lipsius aimed to conciliate Christian moral values with political efficacy and his "Tacitism"

52 Enríquez Gómez, Política angélica, 26, 79, 132. Vila Real was probably quoting Bodin when he wrote: "La obseruancia de la Religion y el exercicio de buenas costumbres, dize vn Filosofo y gentil; haze florecer màs la Monarchia, que la fuerça de poderosos exercitos." Vila Real, Epitome genealógico, 148.

53 See Gaspar Añastro Ysunza's explanations in the dedication of his translation to King Philip III (Jean Bodin, Los seis libros de la republica de Ivan Bodino, traducidos de lengua Francesa, y enmendados catholicamente por Gaspar de Añastro Ysunza [Turin: Herederos de Bevilaqua, 1590], n.p.).

54 Martim de Albuquerque, Jean Bodin na Peninsula Ibérica, Ensaio de Historia das Ideias Políticas e de Direito Pùblico (Paris: Fondation Calouste Gulbenkian, 1978); Harald E. Braun, "Making the Canon? The Early Perception of the République in Castilian Political Thought," in The Reception of Bodin, ed. Howell A. Lloyd (Leiden: Brill, 2013), 257-92. In this sense, it is worthy to note that Política angelica was written in polemical conversation with Quevedo's Politica de Dios, Gobierno de Cristo y Tiranía de Satanás (1617-1626). We know that Quevedo was very influential on Enríquez Gómez's variegated literary work. Quevedo's Politica de Dios shared similar anti-Machiavellian and theocentric views, but it disagreed on the role of the Church within the State, the Spanish monarchy, and the use of the Gospel as a source of political wisdom, instead of the Old Testament. According to Felice Gambin: "[e]s inevitable, por supuesto, a la hora de escribir sobre la Política angelica de Enríquez Gómez, tener en presente el volume quevediano [...]."Felice Gambin, "Es doblar el vivir': La Política angelica entre escritura divina y satánica," in Antonio Enrique Gómez: un poeta entre judaizantes, 143, n. 13. Already Francisco Manuel de Melo in his Hospital das Letras (1657) noticed this influence (Révah, "Un pamphlet," 88-89) Cf. Michael D. McGaha, "Divine' Absolutism vs. 'Angelic' Constitutionalism: The Political Theories of Quevedo and Enríquez Gómez."

55 Lipsius was tremendously influential in the Iberian Peninsula. Perceived as a Catholic anti-Machiavellian thinker, some of his views related to confessional issues were censored by the Inquisition. Cf. Alejandro Ramírez, Epistolario de Justo Lipsio y los Españoles (1577-1606) (Madrid: Castalia, 1966); Beatriz Antón Martínez, "El humanista flamenco J. Lipsio y la receptio del Tacitismo en España," in Humanismo y pervivencia del mundo clásico: actas del I Simposio sobre Humanismo y pervivencia del mundo clásico (Alcañiz, 8 al 11 de mayo de 1990), ed. José María Maestre Maestre and Joaquín Pascual Borea (Càdiz: Universidad de Cádiz, Servicio de Publicaciones, 1993), 1: 237-50. 
saluted strong political regimes and respected freedom of belief. ${ }^{56}$ Lipsius's advice to princes to rule with virtue and prudence, while asking his subjects to remain obedient, departed from a fundamental anthropological division between an external or political and an internal non-political self, which was very appealing to conversos. ${ }^{57}$ Being overtly anti-Bodinian because anti-Machiavellian, Enríquez Gómez endorsed Bodin's notion of "sovereignty" limited by Lipsius's prudence and constancy. ${ }^{58}$ As we shall see, Enríquez Gómez supported absolutist, albeit self-restrained regimes, because only these could fulfill his ideal of "angelic politics" by safeguarding the autonomy of inner conscience from an intrusion of the external sphere. That said, the main personal target of Política angélica was an anonymous churchman called "politico bastardo," who blurred the boundaries of the inner and outer spheres through the cunning cruelty of the Inquisition. This unnamed clergyman was depicted by Enríquez Gómez as an ambitious anti-French Spanish author, who sought to reinforce converso segregation..$^{59}$ Accordingly, "[t]he apostles honored nations by means of baptism and this political author (Estadista) seeks to dishonor sons of the Church who already received baptism. The apostles bound together the Christian community in a mystical body, and this author wishes to disunite them through division and envy." ${ }^{60}$ One of Enríquez Gómez's

56 Quoting Tacitus via Lipsius, Enríquez Gómez reminded that political dissimulation is "the soul of the State" ("el Alma del estado"), provided it is employed with proper means and ethical ends (Enríquez Gómez, Política angélica, 76-81). Also Vila Real praised "el gran Estadista Cornelio Tazito" through Lipsius's interpretations (Vila Real, Epítome genealógico, 146). Enríquez Gómez quoted Tacitus's tyrannical portrait of Nero to compare him with the Inquisition (Révah, "Un pamphlet," 149, 154; Enríquez Gómez, Luis dado de Dios, 10).

57 Cf. Robert Bireley, The Counter Reformation Prince: Anti-Machiavellianism or Catholic Statecraft in Early Modern Europe (Chapel Hill and London: University of North Carolina Press, 1990), 72-100. Cf. the introductions of Jan Waszink and Domenico Taranto: Justus Lipsius, Politica: Six Books of Politics or Political Instruction, ed. Jan Waszink (Assen: Van Gorcum, 2004); Giusto Lipsio, La Constanza, ed. Domenico Taranto (Naples: Bibliopolis, 2004), 9-47.

58 E.g., "que a los Reyes se deue mirar con dos respectos, a sauer, el entendimiento a la soberania; y el sentido al temor" (Enríquez Gómez, Política angélica, 72); “[n]o es buena materia de estado, anteponer la Soberania al bien de la República, querer subir de punto la grandeça por que vaxe el eftado, es romper las cuerdas al ystrumento del buen gouierno, o diuidir enpieças la rueda prinçipal del Relox de la lusítiçia" (Enríquez Gómez, Luis dado de Dios, 13).

59 Enríquez Gómez, Política angélica, 120, 150-51. According to Rèvah (Révah, "Un pamphlet," 86 n. 1), this anonymous anti-converso author also appears cryptically in "Luis dado de Dios," 131.

6o "Los Apostoles honrauan las naciones con el Bauptismo; y eses Estadista dice que se deshonren los hijos de la Iglesia que receuieron el Bauptismo. Los Apostoles vnian en vn 
fictional characters named "Theogonio," revealed that he personally knew the man who disguised his own debased origins by attacking the converso group, thus following the popular dictum: "from the mountains comes he who burns it."61 From information gathered from the book, I will suggest that Enríquez Gómez was referring to the General Inquisitor Juan Adam de La Parra: author of a fierce anti-converso tract (1630), a condemnation of Richelieu's "heretical" alliances with Protestant princes (1634), and a refutation of Braganza's dynastic legitimacy over the Portuguese Crown (1642). ${ }^{62}$ Reasons related to personal prudence might explain such omission. That said, the way Enríquez Gómez addressed the most tangible Iberian counter-example of "angelic politics," the

cuerpo Mistico la congregacion Christiana; $Y$ ese auctor la quiere desunir con la diuision y con la imbidia." Enríquez Gómez, Política angélica, 122.

61 "Philonio. Acuerdome de vn Auctor, mal Politico y peor Christiano, por lisongear vn Ministro de estado, a quien dedico su libro, ya quien adula y lisonjea como quien deseaua alcanzar vna dignidad (q no llebó) dice, tratando sobre esta materia, que no solo no se deue premiar la sangre que por naturaleza esta indiziada en delicto de Religion (defetos de sus passados) pero que se les deue señalar la ynfamia que no cometieron, y cargalles doblados tributos que a las demas, naciones del imperio. Theogio. Ese Auctor conosco yo muy bien, y no os admireis de que condene la virtud, pues nunca la profesó (aun q profeso) ni menos se os haga nouedad el lenguaje que gastó en ese capitulo, por que no ay mayor enemigo del proximo que el que se quiere librar de lo que posee por nacimiento, a ese auctor le fue necessario para calificar su linaje, decir mal de la sangre que le dexaron sus Padres por herencia, y por tales sugetos se dixo, del Monte sale quien al Monte queme. Y Todo quanto esse escribio fue escrito con la pluma de la passion, en el papel del odio, no trato de la tinta que fue la embidia, por que esta la tubo siempre desde la cuna." Ibid., 119-20, 150-51. "Del monte sale quien el monte quema" was also the title of a comedy written in 1627 by Lope de Vega (ed. Ana María Porteiro Chouciño [Santiago de Compostela: Universidad de Santiago de Compostela, 2007]).

62 Juan Adam de la Parra, Pro cautione christiana, in supremis Senatibus Sanctae Inquisitionis, \& ordinum, ecclesia toletana, \& coetibus scholarium obseruata, adversus christianorum proselytos, \& sabbatizantes, nomine, \& specie christianorum (Madrid [?], 163o); idem, Conspiración herético-cristianísima, ed. Joaquín de Entrambasaguas (Madrid: Consejo Superior de Investigaciones Científicas, 1943); idem, Apologetico contra el tirano y rebelde Verganza, y coniurados, arzobispo de Lisboa, y sus parciales: en respuesta a los doze fundamentos del padre Mascareñas (En Zaragoza: por Diego Dormer, 1642). For an analysis of Adam de la Parra's anti-converso tract, see Antonio Domínguez Ortíz, "Una obra desconocida de Adam de la Parra," Revista bibliográfica y documental, 5 (1951): 97-115. For a biography of the General Inquisitor, see Kimberly Lynn, Between the Court and the Confessional. The Politics of Spanish Inquisitors (Cambridge: Cambridge University Press, 2013), 191-237. This name appears in the humoresque disguised form of "devil Parrafiscotado" (el diablo Parrafiscotado), in one of Enríquez Gómez's undated satirical fictions: "La Inquisición de Lucifer y visita de todos los diablos," to denounce "satanic" inquisitors as robbers of their victims (Antonio Enríquez Gómez, La Inquisición de Lucifer y visita de todos los diablos. Critical Edition, Study and Notes by Constance Hubbard Rose and Maxim P.A.M. Kerkhof [Amsterdam-Atlanta, GA: Rodopi, 1982], 5, 10-11). 
Holy Office, shows that he was less interested in attacking concrete inquisitors than in castigating the institution itself. Moreover, by comparing the ecclesiastical estate with the angelic sphere (the nobility with the sublunary sphere and the plebeians with the elements of earth), we can infer that by "angelic politics" he particularly meant the proper relationship of the religious vis-à-vis the political. In this sense, both the Epitome genealógico and Política angélica shared a proclivity to implicitly compare two competing Catholic confessional models, the French versus the Iberian. ${ }^{63}$

Unsurprisingly, Vila Real invoked Richelieu's successful policies with the Huguenot minority and celebrated his peaceful advancement of Catholicism in a religiously divided country. ${ }^{64} \mathrm{He}$ reminded his readers that the Cardinal founded a chair of polemics to lead disputations with Protestant leaders and theologians, on grounds that, "[ $\mathrm{t}]$ he smoothest means to establish the true religion in a kingdom suffering from a disgraceful division is debate." 65 While supporting Catholic education for adults and children, he rewarded leading converted Huguenots to Catholicism with public charges and honors. ${ }^{66}$ For

63 Without explicitly mentioning the Habsburgs, in "Luis dado de Dios," Enríquez Gómez made the following negative overall portrait, which accordingly will inevitably lead to the fall of the Spanish monarchy: "Que fin puede aguardar vn Reyno, que premia malsines, alimenta Cuadrillas de ladrones, como dice S. Agustin, destierra vasallos, deshonrra linajes, ensalza libelos, multiplica ministros, destruye el comerçio, ataxa la poblaçion, ama arbitrios, roba los pueblos, consifca bienes, hace juicios fecretos, no oye las partes, calla los testigos, vende noblezas, condena nobles, alienta gabelas, y aruina el derecho de las gentes: Bien puede floreçer por algún tiempo esta Monarchia, pero entender, que se puede conserbar entre las naçiones, no se yo si abra juiçio humano que lo diga? (Enríquez Gómez, Luis dado de Dios, 118-19).

64 According to Vila Real, Richelieu's: “[o]bligava a sus subditos con el exemplo, y reduzialos con la dotrina [... y] por no faltar en nada, al dever de un Perfecto Prelado, compuso una instruccion Cristiana, en que, con el candor de su virtud, más que con el adorno de la eloquencia, enseña todo lo que conviene a la salud del Alma" (Vila Real, Epítome genealógico, 35). In the preface of a tract written by Richelieu to persuade Protestants to "convert" to Catholicism, which was posthumously published in 1651, the Cardinal claimed that the idea of writing such a book was already conceived when he became the bishop of Luçon in 1606 (Armand-Jean du Plessis Cardinal duc de Richelieu, Oeuvres théologiques, tome II. Traité qui contient la méthode la plus facile et la plus assure pour convertir ceux qui se sont séparés de l'Église, ed. Stéphane-Marie Morgain and Françoise Hildesheimer [Paris: Honoré Champion, 2005], 99).

65 Vila Real, Epítome genealógico, 78.

66 Enriquez Gómez, Política angèlica, 114-15, 138-42. 
Enríquez Gómez, this integrative policy contrasted with the stagnant situation of the conversos in Iberian lands. Accordingly, whereas Richelieu was consistent with Christian values, the segregation of New Christians according to "laws of purity of blood" was unchristian, because it contravened the hospitality of the Bible (e.g., Exodus 11:22), the call to enforce Judaeo-Gentile fraternity in Paul's Epistles, and the positive papal attitude vis-à-vis converted neophytes (such as Nicholas V's condemnation of converso segregation in Toledo in 1499). ${ }^{67}$ Gallicanism thus appears as more authentically Catholic than its Iberian counterpart. Moreover, a comparison of the French and the Iberian experiences not only show that, "to try to reduce the faith of the subjects with violence or severity, even by vanquishing and subjecting them, cannot suppress their opinions [...]." Vila Real and Enríquez Gómez opined that such abuse at the hands of religious power is self-injurious, since "[w]hen a subject knows that he is subdued by taking from him his belongings, he understands that this behavior proceeds from greed and not from charity."68 The Holy Office and the "laws of purity of blood" appear in both books as the worst enemies of the Gospel, for being antithetic, useless, and noxious. In other words, not only was the biased Inquisition a paradoxical "factory of Jews" for pressing many innocent New Christians to confess heretical Jewish behavior to escape harsher punishment, as claimed the Jesuit pro-converso Father António Vieira. ${ }^{69}$ It also teaches actual and potential victims to regard Catholic institutions with cynical contempt and disenchanted eyes. In light of these observations, Vila Real and Enríquez Gómez called for the adoption in Iberia of a minimal dose of freedom of conscience after the example of Richelieu's success in multi-confessional France, since, " $[\mathrm{n}]$ ot all the human hearts are tied by one religion, one loyalty or one faith. Provided only the religion of the prince will be kept and observed in public; families should not be ruined only by signs of envy."70

Let us note, however, that the analogy between French Huguenots and Iberian conversos was not accurate. It is true that much like Iberian New Christians, Huguenots became a disarmed community after the Peace of Alais

67 Ibid., 115; Révah, "Un pamphlet," 140-43.

68 Implicitly, Vila Real criticized the Inquisition's biased machinery: "porque que cosa no ay menos conforme a la rason que querer haser de complisses Profetas, y de delictos enigmas; que por un yerro del entendimiento se castigue la hazienda, no la propia sino la agena, la de su Muger, la de sus hijos que no son culplados. Es apetecer antes riquezas que desear enmienda" (Vila Real, Epitome genealógico, 77-78).

69 António José Saraiva, The Marrano Factory: The Portuguese Inquisition and Its New Christians, $1536-1765$, trans., revised and augmented by H.P. Salomon and I.S.D. Sassoon (Leiden: Brill, 2001), esp. 66-83.

Vila Real, Epitome genealógico, 126; Enriquez Gómez, Política angèlica, 146. 
of 1629, in which they lost their military force and strongholds granted by the Edict of Nantes (as a consequence of Richelieu's successful besiegement of La Rochelle in repression of a Protestant rebellion). At the same time, neither Vila Real nor Enríquez Gómez mentioned the fact that French Protestants retained the right of public worship in many regions, contrasting with the humbler demands to grant freedom of private belief to the New Christian Iberian population..$^{71}$ Hence, the depiction of a tolerated hidden religious community better fitted the actual situation of conversos living in France. It must be borne in mind, however, that such comparison was not new. Already in 1619, the Spanish pro-converso arbitrista Martín González de Cellorigo did much the same. ${ }^{72}$ I think that a contrived analogy between Iberian conversos and French Huguenots aimed to stress the urgency of a full integration for the former, in order to avoid the explosive unrest caused by the latter in France's recent past. Without speaking of civil war, Vila Real and Enríquez Gómez still argued that converso bashing profoundly damaged the socio-economic structures of Iberia, especially Portugal. For, instead of rewarding the ablest among them and reinforcing international commerce and the navy, as Richelieu did in France, the persecution and exclusion of the converso "men of the nation" was economically and demographically disastrous for the country. ${ }^{73}$ Furthermore, the catastrophic consequences of the recent expulsion of the hard-working Morisco minority from Spain, was invoked by Vila Real and Enríquez Gómez as a warning. ${ }^{74}$ Perhaps, paraphrasing the converso arbitrista Duarte Nunes Solis,

71 Menna Prestwich, "The Huguenots under Richelieu and Mazarin, 1629-1661: A Golden Age?" in Huguenots in Britain and their French Background 1550-180o (Basingstoke: Macmillan, 1987), 75-197; Philippe Chareyre, "Trente ans après: de la paix à la grâce: lédit de Nîmes, juillet 1629," in Paix de armes, paix des âmes, 867-89.

72 Claude B. Stuczynski, "Harmonizing Identities: The Problem of Integration of the Portuguese Conversos in Early Modern Iberian Corporate Politics," Jewish History 25 (2011): 229-57.

73 Vila Real, Epitome genealógico, 126. "Anadió coronas à su Corona con la fuerça de sus Armadas, su conservacion consiste en la misma fuerça. Enriqueció sus vassallos con la libertad del Comercio, mientras pues faboreciere a los que le exercitan, durará e aumento de sus riquesas." Ibid., 132; "[d]e las confiscaciones y deshonras de linajes, como habernos dicho, nacen otros danos mayores, como son el turbarse en primer lugar la Republica; pues, cesando el comercio y la poblacion, faltan las navegaciones y las manifacturas; sinm ellas, las rentas reales padecen quiebra, las alcabalas y derechos mueren; y cuando el Principe quiera proveer las armadas, no hallara sino los pastores del campo con quien hacer sus asientos." Révah, "Un pamphlet," 159.

74 Vila Real, Epítome genealógico, 103-7; Enriquez Gómez, Política angèlica, 149-50. The expulsion of the Moriscos from Spain was a major reference in the Iberian Peninsula in debates held around the conversos' fate. Cf. Juan Ignacio Pulido Serrano, "The Unexecuted Plans for the Eradication of Jewish Heresy in the Hispanic Monarchy and the Example 
Vila Real declared that since "[c]ommerce is one of the nerves of the Republic," companies of commerce should be supported by the Iberian monarchs. ${ }^{75}$ That said, whereas by the 1620 s Nunes Solis asked the Habsburg kings to restore Portugal's lost imperial grandeur of the time of King Manuel 1st, by reinvesting in Indian trade with the help of converso merchants, ${ }^{76}$ and Father Vieira was claiming that Portugal's imperial and missionizing vocation would be restored under the new Braganza's monarchs provided they call converso entrepreneurs to invest in the Company of Commerce of Brazil,77 Vila Real and Enríquez Gómez argued that this awaited revival would be implemented by adopting Richelieu's meritocratic Mercantilism. ${ }^{78}$ For the Cardinal understood that meritocracy was one of the main pillars of every enduring regime. ${ }^{79}$ Looking at both books from a converso apologetic perspective, it turns out that both the Epitome genealógico and the Política angélica were innovative in invoking the French model and conservative in elaborating on traditional Paulinian and Mercantilist pro-converso leitmotifs. ${ }^{80}$

of the Moriscos: The Thwarted Expulsion of the Judeoconversos," in The Expulsion of the Moriscos from Spain: A Mediterranean Diaspora, ed. Mercedes García Arenal and Gerard Wiegers (Leiden and Boston: Brill, 2014), 179-96.

75 E.g., "[...] nerbios de vn cuerpo mistico qual es el comercio" (Duarte Gomes Solis, Discursos sobre los comercios de las dos Indias, ed. Moses Bensabat Amzalak [Lisbon: Gráfica Lisbonense, 1943], 153,171. Gomes Solis compared merchants to the "eyes of the Republic" [ibid., 36]).

$7_{6}$ Claude B. Stuczynski, "Portuguese Conversos and the Manueline Imperial Idea: A Preliminary Study," Anais de História de Além-Mar 14 (2013): 45-61.

77 Charles R. Boxer, "Padre António Vieira, S.J., and the Institution of the Brazil Company in 1649," The Hispanic American Historical Review 29 (1949): 397-403.

78 Vila Real, Epitome genealógico, 139. According to Enríquez Gómez: “[...] el Principe que quisiere ver su monarquia prospera, no deshonre los vasallos con libelos infamatorios; antes, a los que se reducieren a la ley del Principe debe honrar y a los hijos en mayor grado, dandoles (si son capaces por su juicio y virtud) oficios nobles en la Republica; pues, con ellos, se levantan los animos a grandes acciones, y a la segunda o tercera generacion, vendran a ser honra ilustre del Imperio. De este gobierno se valio el justo y cristianisimo Rey de Francia Luis XIII, por consejo del Eminente Cardenal Richelieu, el mayor Ministro de Estado que tuvo el orbe, admitiendo en honores publicos a todos aquellos que de la contraria religion se volviesen hijos de la Iglesia: no solo a los hijos que no pecaron, sino a los mismos padres que publicamente observaban la contraria." Révah, "Un pamphlet," 158.

79 "Este prudentisimo Cardenal, gloria de la Francia, conocio que el Imperio adonde se excluia de honor a los vasallos, se habia de perder, como lo sintieron todos los graves politicos." Ibid.

8o Claude B. Stuczynski, "Converso Paulinism and Residual Jewishness: Conversion from Judaism to Christianity as a Theological-Political Problem," in Bastards and Believers: Converts and Conversion between Judaism and Christianity, ed. Pawel Maciejko and Theodore Dunkelgrün (Philadelphia: University of Pennsylvania Press, forthcoming). 
Scholars who have studied Vila Real's and Enríquez Gómez's political views have rightly identified in their writings a political proclivity for French absolutism. ${ }^{81}$ I will argue that these centralistic penchants are intimately intertwined with their confessional aspirations. As mentioned before, Enríquez Gómez claimed an affinity between God's government and the king's politics, in terms of analogy (e.g., God governs the angelical, celestial, and material domains, whereas the king rules over his three Estates: the Church, the Nobility, and the People), emanation (e.g., of the spiritual into the earthly spheres), legitimation (i.e., monarchs are designed by God and are only responsible before Him), and imitation (e.g., monarchs must follow God's teachings and example).$^{82}$ At the same time, a fundamental split occurs in the created world between matter and spirit, leading to a separation between the domain of Caesar and that of God. As a consequence of this duality, the political sphere is separated from the spiritual domain located in human conscience. Therefore, "as human beings, kings have the power over actions of life, by punishing bodies; but they did not receive from the Creator any right upon the souls and freedom of will." 83 The same hold true with respect to the Church. Being God's representatives on earth, members of the clergy must be released from any material consideration. ${ }^{84}$ For, when each member of the mystical body is satisfied with its deserved role ("cada uno esta contento con su imperio"), the king as the head and the Church as the soul, a harmonious "angelical politics" is established. ${ }^{85}$ Elaborating upon Augustine's City of God, Enríquez Gómez explained that the original sin happened when Adam, "the first statesman and

81 By arguing that public religious sins committed by the prince are only to be reprehended secretly and never publicly (Enríquez Gómez, Política angélica, 74), Enríquez Gómez was perhaps reminding the role of the personal confessors of French Kings, which in this sense was different to the more pedagogic task of the Spanish royal confessors (cf. Nicole Reinhardt, Voices of Conscience: Royal Confessors and Political Counsel in SeventeenthCentury Spain and France [Oxford: Oxford University Press, 2016]).

82 Enríquez Gómez, Política angélica, 3-5. "Philonio: Pues que politica en potencia le conviene tener al Principe en el estado? Theogonio: La que tiene Dios con los Angeles." Ibid., 17. Enríquez Gómez also compares the prince with the sun, whose rays, understood as his ministers, give the light to his realm (ibid., 24).

83 "[L]os Reyes como criaturas humanas tienen poder en las acciones de la vida, castigando los cuerpos; pero, sobre las almas y libre albedrio ningun poder les concedio el Criador." Révah, "Un pamphlet," 117.

84 Enríquez Gómez, Política angélica, 40.

85 Ibid., 45 . 
politician of grace lost it, for turning religion into [a matter of] State." ${ }^{\prime 6}$ Other episodes of the Bible supported the claim that (d)evil emerges on earth when the primordial division between the political and the spiritual is transgressed. Thus, the sin committed by the sons of Aaron the priest, Nadav and Avihu, by offering a "strange fire before the Lord, which he commanded them not" (Leviticus 10:1), was interpreted as the intrusion of non-spiritual considerations into the divine. ${ }^{87}$ By adducing these examples, Enríquez Gómez argued against the opinion held by "many political thinkers" (muchos politicos) such as Machiavelli, "who claim that the prince can make of religion a matter of state $[. .$.$] in order to preserve his dominion." At the same time, this intrusion is$ precisely what characterizes the "diabolical politics" in the Iberian Peninsula. ${ }^{88}$ This theological and juridical infringement led Vila Real and Enríquez Gómez to recall the basic Christian right of freedom of conscience, for being the domain of God, while asking conversos to publicly conform to the policies endorsed by the prince, including in religion. By claiming that such principles were inferred from Richelieu's political wisdom, Vila Real was referring to that Gallican juridical tradition of separating the foro externo from the foro interno. That said, I will argue that Vila Real's and Enríquez Gómez's main literary and ideological source was probably Lipsius's Six Books of Politics, or Political Instruction (Politica sive civilis doctrinae libri VI qui ad principatum maxime spectant, 1589). Addressed to "the Emperor, the Kings and the Princes," this book of governance was translated into several languages, including Spanish and French. In Book 4 (of which, predictably, chapters 3, 4, and 13, were deleted by the Spanish "Index of Forbidden Books" of 1612), Lipsius treated the two types of civic prudence of the Prince: human and religious. ${ }^{89}$ Concerning the latter, he argued that social peace and political unity is achieved by allowing in public only the prince's religion. Overt religious diversity will necessarily lead to civil strife, as shown in the religious bloodshed in Europe. Having no juridical rights over sacred matters, the prince should also take in mind the words of the Roman historian Quintus Curtius Rufus: "no King can control

86 "Adan primer estadista y politico de la Gracia la perdio por hazer estado la Religion." Ibid., 42.

87 Enríquez Gómez, Política angélica, 32-34.

88 Ibid., 39, 41.

89 Lipsius, Politica: Six Books of Politics or Political Instruction, 4.2, 387. Both the Latin and the Spanish translation of Lipsius's Politica-i.e., Seis Libros de las Políticas o Doctrina civil, traducidos al castellano por D. Bernardino de Mendoza (Madrid: Imprenta Real, 1604) were also expurgated in 1632 and in 1640. Cf. Jesús Martínez de Bujanda, El Índice de Libros Prohibidos y Expurgados de la Inquisición Española (1551-1819): evolución y contenido (Madrid: Biblioteca de Autores Cristianos, 2016), 101-2, 742. 
hearts as much as he can control tongues." The intrusion of the political into the domain of conscience is both illegal and chimeric. ${ }^{90}$ Therefore, Lipsius distinguished two sorts of religious dissenters: the overt and the hidden..${ }^{91}$ On the one hand, public heretics deserved to be severely punished by the prince for harming civic unity. On the other hand, in chapters 3 and 4 , he suggested that those who keep their "erroneous" beliefs within the private domain of conscience, while externally conform to the prince's religion, should be tolerated. They will progressively change their minds through patient admonition and education. By comparing the Prince to a music player-which was an early modern methaphoric leit-motif-Lipsius reminded that: "[i]f strings are out of tune, you don't tear them out of anger, but step by step bring them back in harmony." Only in this way the Prince will fulfill the Gospel: to make "the multitude of believers have one heart and one mind" (Acts 4:32)..$^{92}$ In chapter 13 Lipsius even approved the fact that the Prince should use "a bit of the sediment of deceit" to virtuously rule his subjects, since human beings are often cunning and bad. Therefore, a seeming policy of religious toleration employed as a deceitful means to obtain gradual religious homogeneity appeared to Lipsius as honorable and useful. ${ }^{93}$ Following Lipsius, Vila Real and Enríquez Gómez acknowledged the political harm caused by public religious deviance, but commended the help given by Richelieu to "heretical" Protestants outside France, on grounds that international alliances belonged to the political domain of the "Law of Nations" (Ius Gentium). ${ }^{94}$ For the same reason, Vila Real endorsed Richelieu's prohibition of Roberto Bellarmino's Tractatus de potestate Summi Pontificis in rebus temporalibus, adversus Gulielmum Barclay (1610), for granting the Pope indirect power ("potestas indirecta") over secular affairs, thus encouraging sedition and political unrest. ${ }^{95}$ French absolutism was one of Janus's faces of Gallican confessionalism.

In fact, these views were also related to a well-established tradition of French skepticism promoted by Michel de Montaigne on the necessity of adhering to norms dictated by the public sphere (au dehors) while maintaining

\footnotetext{
90 Lipsius, Politica: Six Books of Politics or Political Instruction, 4.4, 395.

91 Ibid., 4.3, 391.

92 Ibid., 4.4, 397. On the historical conditions which explains the dissemination of the analogy between the political ruler and the music player in early modern times, see: Ruth HaCohen and Yaron Ezrahi, Composing Power, Singing Freedom: Overt and Covert Links between Music and Politics in the West (Tel Aviv: Van Leer Institute Press-Hakibbutz Hameuchad Publishing House, 2017), 26-97 [Hebrew].

93 Ibid., 4.13, 507.

94 Vila Real, Epitome genealógico, 115; Enríquez Gómez, Política angélica, 51-54.

95 Vila Real, Epitome genealógico, 135-36.
} 
freedom of thinking within the inner-self (au dedans). ${ }^{96}$ Pierre Charron's $O f$ Wisdom (De la sagesse, 1601), a committed follower of Montaigne and an enthusiastic reader of Lipsius, further elaborated on this distinction. Accordingly, political obeisance must never be confused with inner truth or justice, even if public accommodation stems from the simple wish to live wisely in peace. ${ }^{97}$ Charron's views contributed to the development of concealed forms of doubt and unbelief and the crystallization of erudite forms of libertinism in seventeenth-century France. ${ }^{98}$ One of these libertine savants was François de La Mothe Le Vayer, a supporter of Richelieu and a notorious anti-Spaniard. ${ }^{99}$ In his De la contrariété d'humeurs qui se trouve entre certaines nations, et singulièrement entre la Française et l'Espagnole, ou De l'antipathie des Français et des Espagnols (1636), he responded to Spanish criticism against France's toleration of Huguenots and political alliances made with Protestant princes by arguing that these were more appropriate ways to advance Catholicism than the Iberian hypocritical mode. He recalled Machiavelli's explanation of the expulsion of the Jews from Spain in 1492 in chapter 21 of The Prince. Purportedly grounded on religious zeal, it stemmed from purely political motivations ("ne pouvoient pas avoir d'autre fondement que la consideration d'Estat"). As proof of this ruse, he noted that many Catholic princes, including the Pope, accepted

96 Anna Maria Battista, Politica e morale nella Francia dell'età Moderna, ed. Anna Maria Lazzarino Del Grosso (Genoa: Name, 1998), 251-91.

97 In the second chapter of the second book of Of Wisdom titled: "An universal and plain liberty of spirit, both in Judgement and Will, the second disposition to Wisdom," Charron argued: "[f]or I will that in all outward and common actions of our life, and in whatsoever is ordinarily used, a man should agree and accommodate himself to the common sort; for our rule extendeth not itself to that which is outward, and to the action, but to that which is within, the thought, and secret of and inward judgement" (Pierre Charron, Of Wisdom: Three Books; Made English by George Stanhope from the Best Edition, Corrected and Enlarged by the Author a Little Before his Death [London: Printed for M. Gillyflower, 1697], 217). Cf. Domenico Taranto, Pirronismo e assolutismo nella Francia del'6oo. Studi sul pensiero politico dello scetticismo da Montaigne a Bayle (1580-1697) (Milan: Franco Angeli, 1994), 63-105.

98 French Libertines generally supported absolutist regimes and endorsed dissimulation as a way of living separated from the mob. See René Pintard, Le Libertinage érudit dans la première moitié du XVII ème siècle. Nouvelle édition augmentée d'un avant-propos et de notes et réflexions sur les problèmes de l'histoire du libertinage (Geneva and Paris: Slatkine, 1983), 539-64; Jean-Pierre Cavaillè, Dis/simulations. Jules-César Vanini, François La Mothe Le Vayer, Gabriel Naudé, Louis Machon et Torquato Accetto: religion, morale et politique au $X V I I^{e}$ siècle (Paris: Honorè Champion, 2002).

99 On La Mothe Le Vayer's pro-Richelieu, libertine and anti-Spanish views see Taranto, Pirronismo ed assolutismo nella Francia del'6oo. Studi sul pensiero politico dello scetticismo da Montaigne a Bayle (1580-1697), 107-29; François de La Mothe Le Vayer, Dialogues faits à l'imitation des Anciens, ed. Bruno Roche (Paris: Honoré Champion, 2015), 12-17. 
Jews in their domains. ${ }^{100}$ Moreover, he labelled the Spanish Inquisition an impious mockery against God and men (“[...] c'est vouloir avec impieté prendre Dieu pour crédule aussi bien que les hommes") which was inefficacious, for everybody knows that converso Judaizers, Moriscos, as well as heterodox alumbrados still prosper in Iberia (sic!) ${ }^{101}$ Quoting Lactance's Divine Institutes (book 5, chapter 19), La Mothe Le Vayer encapsulated the reason for Spain's confessional failure: "when religion is imposed it ceases to be religious." ${ }^{102}$ Vila Real and Enríquez Gómez were probably acquainted with such libertine voices. However, it ought to be kept in mind that almost every early modern political thinker was aware that religion was (also) a serious political matter. Thus, the Spanish diplomat and writer Diego de Saavedra Fajardo grounded his defense of Spain's religious homogeneity on such premises. ${ }^{103}$ Moreover,

100 François de La Mothe Le Vayer, "De la contrariété d'humeurs qui se trouve entre certaines nations, et singulièrement entre la Française et l'Espagnole, ou De l'antipathie des Français et des Espagnols," in Oeuvres de François de La Mothe Le Vayer, Tome 2 (Paris: Louis Billaine, 1669), 22-23. In the posthumously published pamphlet: En quoi la piété des François diffère de celle des Espagnols, dans une profession de même Religion, he similarly argued: “[...] car de vouloir faire passer pour oeuvres de pieté de grandes expulsions, tantost des Juifs, \& tantost des Morisques, hors de l'Espagne, c'est se moquer de Dieu \& du Monde; où personne n'a ignoré qu'il n'y eust plus de crainte, d'avarice \& d'inhumanité en tout cela, que de Religion, qui souffre les Juifs dans Rome, \& en assez d'autres lieux trés Catholiques" (117).

101 "Il n'y a donc pas beaucoup de quoi les Espagnols se puissant vanter d'avoir tant exterminé de creatures humaines sous un faux pretexte de Religion, comme ils n'ont pas non plus grand sujet de vouloir passer pour bien meilleurs Chréstiens que les autres, n'y ayant pas cent cinquant ans que le Mahumetisme \& l'infidelité possedoient encore les plus considerable parties de l'Espagne. Aussi que nonobstant ce zele inconsideré des nouveaux Chrétiens, ou plustost cette precaution craintive \& ordinaire aux Conquerans, chacun sçait qu'il n'y a pas moins des Maranes, d'Alumbrados, de Juifs, \& des Mahometans secrets en Espagne, qu'il peut avoir de Huguenots reconnus, \& par consequent moins à craindre dans la France." Idem, "De la contrariété d'humeurs qui se trouve entre certaines nations, et singulièrement entre la Française et l'Espagnole," 22-23, 24-25.

102 Ibid., 24.

103 E.g., "Aunque (como hemos dicho) la justicia armada con las leyes, con el premio y castigo, son las colunas que sustentan el edificio de la república, serían colunas en el aire si no se asentasen sobre la base de la religión, que es el vínculo de las leyes [...] tan necesario es en las repúblicas este temor, que a muchos impíos pareció invencióm política la religión. [...] El pueblo se dividirá en opiniones, la diversidad dellas desunirá los ánimos, de donde nacerán las sediciones y conspiraciones, y dellas las mudanzas de repúblicas y dominios. Mas píncipes vemos despojados por las opiniones diversas de religión que por las armas. Por resto el Concilio Toletano sesto ordenó que a ninguno se diese posesión de la corona si no hubiese jurado primero que no permitiría en el reino quien no fuese cristiano. [...] Si tal ficción es arte política para unir los ánimos y mantener la república, mejor se alcanzará con la verdadera religión que con la falsa, porque ésta es caduca y aquella eternamente durable." Diego de Saavedra y Fajardo, Empresas políticas, ed. Sagrario López Poza (Madrid: Cátedra, 1999), 388-9o. "La religión, si bien es vínculo de república (como 
according to Giovanni Botero's The Reason of State (1589), an extremely influential book in Iberia, Christianity is the best means to govern, because through this specific religion the prince has access to his subjects' inner consciences. ${ }^{104}$ However, Saavedra Fajardo and Botero never intended to transform religion into a mere political tool, nor did Lipsius, Montaigne, or Charron. Richelieu, who was deeply influenced by these writers, promoted religious unity in his country while upholding Catholic truth. ${ }^{105}$ By adhering to the idea that faith depends upon personal conviction, he masterfully leveraged the political sphere as a way of indirectly influencing the inner sphere of his subjects' consciences. Richelieu was the very embodiment of the Gallican politique, and Vila Real and Enríquez Gómez followed closely in his footsteps. The former acknowledged that: " $t]$ here is no more harmful thing in a republic than religious diversity," because: "one always lives with suspicion, having the enemy inside (teniendo de las puertas adentro el enemigo). Many think that it is impossible to preserve the State in such diversity," he added, since: "this way of believing differently is a continuous reason to make rebellion [...]."106 Acutely aware of the dangerous potential of freedom of conscience, Richelieu appears as a model to be followed. Whereas the Cardinal violently suppressed the military power of the rebellious Huguenots in La Rochelle, he was lenient with his docile unarmed "heretical" subjects and advanced "sweet" means to convert the pacified

hemos dicho) es la que más la desune y reduce a varias formas de gobierno, cuando no es una sola, porque no puede haber concordia ni paz entre los que sienten diversamente de Dios. Pues si la diversidad en las costumbres y trajes hace opuestos a los ánimos, qué hará la inclinación y fidelidad al Autor de lo criado, y la rabia de los celos del entendimiento del modo de entender lo que tanto importa? La ruina de un Estado es la libertad de consciencia." Ibid., 708.

104 Giovanni Botero, The Reason of State, ed. P.J. and D.P. Waley (New Haven: Yale University Press, 1956), Book 2, chapter 16.

105 Jean Daniel Charron, The "Wisdom" of Pierre Charron. An Original and Orthodox Code of Morality (Chapel Hill: The University of North Carolina Press, 1960); Anna Maria Battista, Alle origini del pensiero politico libertino: Montaigne e Charron (Rome: Universita' degli Studi di Roma Istituto di Studi Storico-Politici della Facolta' di Scienze Politiche, 1966); William F. Church, Richelieu and Reason of State (Princeton, NJ: Princeton University Press, 1972), 75-78; Bergin, The Politics of Religion in Early Modern France, 124-32.

106 Vila Real, Epitome genealógico, 100-1. Acknowledging the difference between the spiritual and the material spheres, Enríquez Gómez pleaded for a convergence between the two ("todo el grave peso de una Monarquia consiste en la Religion, y toda la conservacion del Estado consiste en que la Religion se conserve intacta y sin mancha alguna. La fe pide pureza de animo, el Reino conformidad de corazones"). Heresy disturbs political and religious tranquility but it is inevitable ("[p]ero, como no hay cuerpo sin humores ni materia sin dolor, asi es fuerza que, por pecados del pueblo, se levanten hereticas opiniones que turben la paz del espiritu y traigan en perpetuo desasosiego el estado espiritual y temporal" [Révah, "Un pamphlet," 119]). The task of the prince is to remediate this impasse with justice and moderation. 
Huguenot community. Without abrogating the Edict of Nantes, Richelieu aimed to progressively obtain the unity of the Catholic faith, so crucial to political stability and spiritual salvation. Vila Real and Enríquez Gómez probably paraphrased Lipsius, personally experienced the foro interno/foro externo juridical tradition when living in France, and perhaps they were acquainted with libertine views, but they openly embraced Richelieu's Catholic-politique sense of confessional "prudence." "Richelieu in Marrano Garb": Meaning and Implication

Moreover, both Enriquez Gómez and Vila Real followed almost verbatim the anti-Spanish propaganda then propagated by Richelieu and his advocates, in which the cruelties and corruption of the Inquisition represented a perfidious way of using religious piety to obtain political and economic gains. "In my opinion," repeated Enríquez Gómez ad nauseam, "the worse crimes are committed under the cloak of religion." 107 Therefore, the real Machiavellians are not the French politiques, as the Spanish claimed, but the Spaniard devotees. In the words of Paul Hay Du Chastelet, one of Richelieu's partisan writers, in Spain: "the religious appearance greatly serves the case of the princes" (Lapparence de religion sert grandement aux affaires des Princes). ${ }^{108}$ Seventeenth-century French political discourse was polemically constructed vis-à-vis the Spanish and vice versa. ${ }^{109}$ Attacks against the Iberian Inquisitions, then, were neither solely a converso obsession nor mere episodic outbursts of anti-Spanish feeling. Such belligerence was one of the major ways of distinguishing the French from the Iberians. Paradoxically, then, when the time came to offer concrete solutions, neither Enríquez Goméz nor Vila Real asked for the complete abrogation of the Holy Office. Rather, they sought to transform this well-established Iberian institution, while insisting on friendlier ways to correct and convert heretics. ${ }^{110}$ Even if they were inspired by an idealized image of Richelieu's

107 "[P]or que a mi ver los mayores delitos que se cometen, es con capa de Religion" (Enríquez Gómez, Política angélica, 102).

108 Quoted by Etienne Thuau, Raison d'État et pensée politique à l'époque de Richelieu (Paris: Armand Colin, 1966), 294.

109 Henry Méchoulan, "L'Espagne dans le miroir des textes français," in L'Etat baroque, 42146; Jean-Frédéric Schaub, La France espagnole. Les racines hispaniques de l'absolutisme français (Paris: Éditions du Seuil, 2003). María Soledad Arredondo, Literatura y propaganda en tiempo de Quevedo: guerras y plumas contra Francia, Cataluña y Portugal (Madrid: Vervuert, 2011), esp. 92-109.

110 Stefania Pastore, "A proposito di Matteo 18, 15: 'Correctio fraterna' e Inquisizione nella Spagna del Cinquecento," Rivista Storica Italiana 113 (2001): 323-68. 
Catholic evangelization of the Huguenots, Vila Real and Enríquez Gómez called to implement the peaceful missionary methods employed by Jesuits with "heathens" in distant colonial lands for the New Christians living in Portugal, much as Father Vieira was then striving to do. ${ }^{111}$ In doing so, they propagated an old pro-converso aspiration: that New Christians should be converted by the word and not by the sword. Enríquez Gómez suggested that tribunals of the Holy Office will be led by three members of the clergy (a Jesuit, a Capuchin, and a secular priest) carefully chosen by the king. Only after being secretly admonished and pardoned twice, "stubborn heretics" will be judged publicly, without employing anymore anonymous denunciations, confiscation of property, or secret and unlimited stays in prison. Those found hopelessly guilty will be punished to death without mercy (only the king could exceptionally change the sentence with exile). ${ }^{112}$ During the Habsburg dynastical period (1578-1640) pro-converso elements in Portugal sought to reform the biased Inquisition after the more reliable Castilian model and under Braganza's dynastical "restoration," this was permuted by invoking the Roman Holy Office. ${ }^{13}$ Vila Real and Enríquez Gómez called to combine the French confessional experience (e.g., the "Burning Chamber") and the old evangelical tradition of "fraternal emendation" (correctio fraterna) after Matthew 18:15, with the Iberian overseas ideal of evangelization (e.g., the Jesuits). ${ }^{114}$ Such creative adaptations wonderfully encapsulate what I meant by "Richelieu in Marrano garb."

Finally, I will briefly argue against those scholars who insist on the hierocratic-sacred character of the French monarchy, as portrayed by Vila Real and Enríquez Gómez. It is true that in the latter's Luis dado de Dios (1645), the French king was depicted as the embodiment of the ideal biblical monarch. ${ }^{115}$ The title of Politica angélica is highly telling in this respect. However, like most French political thinkers, at least until Jacques-Bénigne Bossuet, the divine nature

111 Révah, "Un pamphlet," 152-53. E.g., António Vieira, Escritos sobre os Judeus e a Inquisição, ed. José Eduardo Franco and Pedro Calafate (Lisbon: Temas e Debates, 2015), 31-46.

112 Révah, "Un pamphlet," 162-68.

113 Ana Isabel Lopez-Salazar Codes, "'Che si riduca al modo di procedere di Castiglia.' El debate sobre el procedimiento de inquisitorial portugués en tiempos de los Austrias," Hispania Sacra 59 (2007): 243-68.

114 Pastore, "A proposito di Matteo 18, 15"; idem, Il Vangelo e la spada. L'Inquisizione di Castiglia e i suoi critici (1460-1598) (Rome: Edizioni di Storia e Letteratura, 2003), 214-18.

115 "La Competencia en el estado, fue siempre causa de fatales ruynas, por que donde falta la vnion falta la virtud, y faltando ella sobra el odio, ydra tan dificultosa de cortar sus cabeças, como lo es querer retroceder el cursode la naturaleza: El inferior quando se ve faboreçido, no respeta al superior, y es yndigna acción del poder, conçeder esta licençia al subito. Raçon de estado sera anteponer lo Soberano al valimento, no dando lugar á que se quexe el monte, de la Soberanía del valle" (Enríquez Gómez, Luis dado de Dios, 44-45). 
of kings served more as a juridical starting point than as a modus operandi. ${ }^{116}$ Already in Luis dado de Dios, the good monarch was defined as a prince who firmly governs his kingdom with justice and disinterested piety. Whereas a strong and unrestrained government is a tyranny, a weak prince who is led by a divided Court and disobedient society cannot ensure those moral and religious values. A limited idea of sovereignty can be detected throughout Vila Real's and Enríquez Gómez's writings, as a means to solve the converso problem of integration. It is unsurprising if Enríquez Gómez commented on the same emblem of "Alliances" from Andrea Alciato's Book of Emblems (first edition, 1531), which was previously invoked by the pro-converso Cellorigo. ${ }^{117}$ Both authors chose to illustrate Bodin's sense of royal sovereignty by using Alciato's image of the prince as a lute-player and the strings as the different estates of the kingdom. ${ }^{118}$ That said, whereas Cellorigo claimed that the string of the plebeian "third estate" artificially created a New Christian string-less estate from hatred and envy, Enríquez Gomez argued that the too-dominant and intruding string of the clergy destroyed the entire musical instrument. ${ }^{119}$ In order to solve the converso problem in a disharmonious society, the king must firmly intervene: as a lute player, according to Cellorigo, and as a lute-maker, according to

116 Nicholas Henshall, The Myth of Absolutism: Change and Continuity in Early Modern European Monarchy (London: Longman, 1992); Richard Tuck, The Sleeping Sovereign: The Invention of Modern Democracy (New York: Cambridge University Press, 2015), chapter 1.

117 Stuczynski, "Harmonizing Identities: The Problem of Integration of the Portuguese Conversos in Early Modern Iberian Corporate Politics."

118 Much like the lute's strings, loyalty and trust in the lute player or sovereign are required from the subjects as the basis of political legitimacy: "[e]l edificio de la potencia ideal sera fundado sobre las fuertes columnas de la lealtad: las cuerdas de la republica haran perfecta la musica en el instrumento del gobierno, Porque siendo su verdadero Orpheo el Principe, la armonia de las vozes acudira al temple de su maestro" (Enríquez Gómez, Política angelica, 26-28). Cf. Enríquez Gómez, Luis dado de Dios, 45.

119 "De nuestra Politica Angelica quereis sacar el gobierno que debe tener el Principe Cristiano para castigar los delitos de religion; yo os dire los medios por donde se puede conseguir una ley justa y, para venir en conocimiento de ella, nos valdremos de aquel emblema del sabio Alciato que dice: 'El imperio ha de ser un istrumento templado.' Y los mejores escritores, o estadistas por mejor decir, quieren que sea de tres Ordenes Eclesiasticas, Nobles y Plebeyas; estas ha de tocar el Principe con tanta orden que cada una ocupe su lugar: la primera voz Eclesiastica suave, la segunda Noble grave, la tercera Plebeya baja, con cuya armonia andara el Imperio concertado; pero si la cuerda Eclesiastica sonare fuerte y la Noble baja y la Plebeya alta, ni el oido de la razon podra escuchalla ni la prudencia oilla. Asentada esta razon por basa de este edificio, decimos que si los Ministros Eclesiasticos subieren de punto el orden y tiraren la cuerda del estado espiritual, es fuerza que se han de llevar la puente y tapa del istrumento." Révah, “Un pamphlet," 161-62. 
Enríquez Gómez. ${ }^{120}$ I think that such differences in diagnosis and prognosis did not solely stem from a different interpretation of sovereignty after the political models employed by the two authors (the corporatist Habsburg model of Cellorigo vs. the more centralistic French of Enríquez Gómez). The rise of the Braganza royal dynasty, instead of the Habsburgs, aroused initial enthusiasm and expectation among pro-converso elements, including Vila Real and Enríquez Gómez. These believed that by adapting the French confessional model into the Iberian contexts the converso problem would finally be solved. Being "liberated" from the "tyrannical" Habsburgs, the Portuguese Braganza dynasty would receive from the powerful French military, economic, and diplomatic assistance and political inspiration. However, whereas French concrete help was insufficient, brief, and disappointing, the new, weak Portuguese monarchs could not overcome the power of the Holy Office and the anti-converso elements within the kingdom. Despite the protestations of the Inquisition and the clergy, the Luso-Dutch treaty (of 12 June 1641) enabled Dutchmen staying in Portugal to practice religious worship on the ships and in the homes of official emissaries and ambassadors, thus enlarging the inquisitorial immunity obtained by English traders in $1630 .{ }^{121}$ None of Vila Real's and Enríquez Gómez's suggestions could be fulfilled, despite support given by King John IV to obtain the integration of the New Christian group for economic and state-building reasons. Portugal's Holy Office was a powerful institution supported by most of the nobility, the clergy, and the "people" represented in the Parliament, because it was perceived as the ultimate defender of its most traditional sociopolitical and religious institutions. ${ }^{122}$ Mostly through Father Vieira's and Jesuit efforts, from 1649 to 1656 , the Inquisition temporarily suspended the confiscation of the detainee's belongings. ${ }^{123}$ However, no concession was given to conversos' rights of freedom of conscience as was pleaded by Vila Real and

120 In the first part of his Politica Angélica, Enríquez Gómez depicted Alciato's emblem in the following way: "Aplicó Alciato el gouierno, y Politica del Principe a un instrumento Templado; El que acuerda este instrumento es la sabiduria; si el Principe haze mas estimacion de vna cuerda, que de otra, subiendo de punto esta y bajando aquella, muy malsonará el instrumento, Peligrosa disonancia hará necessario es que con sabiduria fauoresca el merito, y con cordura castigue el delicto" (ibid., 95).

121 Ana Isabel López-Salazar Codes, "Puderão mais os inquisidores que o rey.' Las relaciones entre el Santo Oficio y la Corona en el Portugal de la Restauración (1640-1668)," Cuadernos de Historia Moderna 39 (2014): 143. Cf. Leslie M.E. Shaw, Trade, Inquisition and the English Nation in Portugal (Manchester: Carcanet, 1989).

122 Giuseppe Marcocci and José Pedro Paiva, História da Inquisição Portuguesa, 1536-1821 (Lisbon: A esfera dos Livros, 2013), 173-75.

123 Israël Salvator Révah, "Les Jésuites portugais contre l'Inquisition: la campagne pour la création de la Compagnie Générale du Commerce du Brésil," in Etudes portugaises, ed. 
Enríquez Gómez. As I have tried to show, "Richelieu in Marrano garb" required a major transformation of Iberian political structures and confessional policies. Without a "Portuguese Richelieu," a Gallican adaptation could never be implemented on Iberian soil.

In his edition of the second part of Enríquez Gómez's Política angélica, Révah argued that only questions related to "purity of blood" and the Inquisition "revealed an essential aspect of Marrano thought."124 Such a view accounts for his decision to privilege this section over the first part of the Politica angélica and Vila Real's Epitome genealógico. Burning questions, such as the confiscation of the detainee's belongings by the Holy Office, did stand at the center of pro-converso political agency at those historical moments. Even Vila Real confessed to the inquisitors to have written a tract on the subject. ${ }^{125}$ In this sense, Vila Real, Enríquez Gómez, Father Vieira, and other Jesuits and converso "men of the nation" living in Iberia or in the French Sephardic diaspora, were intimately interrelated. ${ }^{126}$ In this article, however, I aimed to reassess what the Portuguese writer Francisco Manuel de Melo ironically meant in his Hospital das Letras (1657), by calling Vila Real and Enríquez Gómez "two Portuguese grafted as French" (esses dous Portugueses enxertados em Galos) and "Gallicized political writers" (politicos franceses), through the fictional characters of "Quevedo," "Lipsius," and himself. ${ }^{127}$ I suggested that, along with other converso and pro-converso elements, such as New Christians living in late-sixteenth-century Bragança, Vila Real and Enríquez Gómez were highly selective, creative, and sophisticated thinkers of French and Iberian confessionalism. ${ }^{128}$ At the same time, their broad French-Gallican experiences and European confessional knowledge emerge as a major converso concern. Not satisfied to be merely "victims" of Iberian confessionalism, they became creative "agents" of French Gallicanism in the Iberian Peninsula. In doing so,

Charles Amiel (Paris: Centre Calouste Gulbenkian, 1975), 155-83; Marcocci and Paiva, História da Inquisição Portuguesa, 1536-1821, 185-86.

124 "Au fond, seul le Quatrieme Dialogue de cette première partie (pp. 106-153) révélait un aspect essentiel de la pensée du Marrane." Révah, "Un pamphlet," 91.

125 "Tambem escreveu por ordem do marquez de Niza uma memoria sobre a conveniencia de S.M. tirar o confisco aos culpados e presos pelo Santo-Officio, tanto de sus bens, como dos alheios que em seu poder tivessem, para assim se augmentar o comercio." Ramos Coelho, Manuel Fernandes Villa Real e o Seu Processo na Inquisição de Lisboa, $5^{2}$.

126 Natalia Muchnik, "Antonio Vieira y la diaspora sefardí en el siglo XVII," in António Vieira, Roma e o universalismo das monarquias portuguesa e espanhola, ed. Pedro Cardim and Gaetano Sabatini (Lisbon: Centro de História de Além-Mar, 2011), 97-119.

127 Quoted by Révah, "Un pamphlet," 87-88.

128 "Au fond, seul le Quatrieme Dialogue de cette première partie (pp. 106-153) révélait un aspect essentiel de la pensée du Marrane." Ibid., 91. 
they sought to contribute, in their own particular ways, to political and religious modernity.

\section{Bibliography}

Adam de la Parra, Juan. Apologetico contra el tirano y rebelde Verganza, y coniurados, arzobispo de Lisboa, y sus parciales: en respuesta a los doze fundamentos del padre Mascareñas. En Zaragoza: por Diego Dormer, 1642.

Adam de la Parra, Juan. Conspiración herético-cristianísima. Edited by Joaquín de Entrambasaguas. Madrid: Consejo Superior de Investigaciones Científicas, 1943.

Adam de la Parra, Juan. Pro cautione christiana, in supremis Senatibus Sanctae Inquisitionis, \& ordinum, ecclesia toletana, \& coetibus scholarium obseruata, adversus christianorum proselytos, \& sabbatizantes, nomine, \& specie christianorum. Madrid (?), 1630.

Albuquerque, Martim de. Jean Bodin na Peninsula Ibérica, Ensaio de Historia das Ideias Políticas e de Direito Pùblico. Paris: Fondation Calouste Gulbenkian, 1978.

Amzalak, Moses Bensabat. As relações diplomaticas entre Portugal e a França no reinado de D. João IV (1640-1656): documentos e notas. Lisbon, n.p. 1934.

Antón Martínez, Beatriz. "El humanista flamenco J. Lipsio y la receptio del Tacitismo en España." In Humanismo y pervivencia del mundo clásico: actas del I Simposio sobre Humanismo y pervivencia del mundo clásico (Alcañiz, 8 al 11 de mayo de 199o). Edited by José María Maestre Maestre and Joaquín Pascual Borea, 1: 237-50. Càdiz: Universidad de Cádiz, Servicio de Publicaciones, 1993.

Arquivos Nacionais/Torre do Tombo. Inquisição de Coimbra, processos ns. 484, 66o2, $7934,8798,8800,9269$.

Arredondo, María Soledad. Literatura y propaganda en tiempo de Quevedo: guerras y plumas contra Francia, Cataluña y Portugal. Madrid: Vervuert, 2011.

Baião, António. Episódios dramáticos da Inquisição portuguesa. Rio de Janeiro: Álvaro Pinto Editor, 1924.

Balasse, Céline. 1306. L'expulsion des juifs du royaume de France. Brussels: de Boeck, 2008.

Barbiche, Bernard. "LÉdit de Nantes et son enregistrement: génèse et publication d'une loi royal." In Paix de armes, paix des âmes, ed. Paul Mironneau and Isabelle Pébay-Clottes, 251-26. Paris: Imprimerie nationale, 2000.

Barreto, João Franco. Relação da embaixada a França em 1641, por João Franco Barreto. Reimpressa com noticias e documentos elucidativos por Carlos Roma Du Bocage e Edgar Prestage. Coimbra: Imprensa da Universidade, 1918.

Battista, Anna Maria. Alle origini del pensiero politico libertino: Montaigne e Charron. Rome: Universita degli Studi di Roma Istituto di Studi Storico-Politici della Facolta di Scienze Politiche, 1966. 
Battista, Anna Maria. Politica e morale nella Francia dell'età Modern. Edited by Anna Maria Lazzarino Del Grosso. Genoa: Name, 1998.

Bedos-Rezak, Brigitte. “Tolérance et raison d'État: le problème Juif." In L'Etat baroque. Textes réunis sous la direction d'Henry Méchoulan, étude préliminaire d'Emmanuel Le Roy Ladurie, préface de André Robinet, 243-87. Paris: Librairie philosophique J. Vrin, 1985.

Benedict, Philip. "The Huguenot Population of France, 160o-1685: The Demographic Fate and Customs of a Religious Minority." Transactions of the American Philosophical Society 81 (1991): 1-164.

Bergin, Joseph. The Politics of Religion in Early Modern France. New Haven and London: Yale University Press, 2014.

Bireley, Robert. The Counter Reformation Prince: Anti-Machiavellianism or Catholic Statecraft in Early Modern Europe. Chapel Hill and London: University of North Carolina Press, 1990.

Blamont, Jacques. Le lion et le moucheron. Histoire des Marranes de Toulouse. Paris: Odile Jacob, 2000.

Bodian, Miriam. "The Portuguese Jews in Amsterdam and the Language of Liberty." Journal of Levantine Studies 6 (2016): 313-32.

Bodin, Jean. Los seis libros de la republica de Ivan Bodino, traducidos de lengua Francesa, y enmendados catholicamente por Gaspar de Añastro Ysunza. Turin: Herederos de Bevilaqua, 1590.

Botero, Giovanni. The Reason of State. Edited by P.J. and D.P. Waley. New Haven: Yale University Press, 1956.

Boxer, Charles R. "Padre António Vieira, S.J., and the Institution of the Brazil Company in 1649." The Hispanic American Historical Review 29 (1949): 397-403.

Brambilla, Ellena. Alle origini del Sant'Uffizio. Penitenza, confessione e giustizia spirituale dal medioevo al XVI secolo. Bologna: Il Mulino, 2000.

Brambilla, Ellena. La giustizia intollerante. Inquisizione e tribunali confessionali in Europa (secoli $I V-X V I I I)$. Rome: Carocci, 2006.

Braun, Harald E. "Making the Canon? The Early Perception of the République in Castilian Political Thought." In The Reception of Bodin. Edited by Howell A. Lloyd, 257-92. Leiden: Brill, 2013.

Brazão, Eduardo. A diplomacia portuguesa nos séculos XVII e XVIII. Lisbon: Editorial Resistência, 1980.

Broens, Nicolás. Monarquía y capital mercantil: Felipe IV y las redes comerciales portuguesas (1627-1635). Madrid: Ediciones de la Universidad Autónoma de Madrid, 1989. Cavaillè, Jean-Pierre. Dis/simulations. Jules-César Vanini, François La Mothe Le Vayer, Gabriel Naudé, Louis Machon et Torquato Accetto: religion, morale et politique au XVII ${ }^{e}$ siècle. Paris: Honorè Champion, 2002. 
Chareyre, Philippe. "Démographie et minorités protestantes." Bulletin de la Société de l'Histoire du Protestantisme Français 148 (2002): 867-89.

Chareyre, Philippe. "Trente ans après: de la paix à la grâce: l'édit de Nîmes, juillet 1629." In Paix de armes, paix des âmes. Edited by Paul Mironneau and Isabelle PébayClottes, 867-89. Paris: Imprimerie nationale, 2000.

Charron, Pierre. Of Wisdom: Three Books; Made English by George Stanhope from the Best Edition, Corrected and Enlarged by the Author a Little Before his Death. London: Printed for M. Gillyflower, 1697.

Church, William F. Richelieu and Reason of State. Princeton, NJ: Princeton University Press, 1972.

Coelho, António Borges. "Manuel Fernandes Vila Real no discurso político dos primeiros anos da Restauração." In A união ibérica e o mundo atlântico. Edited by Maria da Graça A. Mateus Ventura, 285-306. Lisbon: Colibri, 1997.

Coelho, José Ramos. Manuel Fernandes Villa-Real e o seu processo na Inquisição de Lisboa. Lisbon: Empreza do Ocidente, 1894.

Cottret, Bernard. 1598, L'Édit de Nantes. Paris: Perrin, 1997.

Dahan, Gilbert, and Élie Nicolas, eds. L'expulsion des Juifs de France, 1394. Paris: Cerf, 2004.

De Paolis, Velasio. "Natura e funzione del foro interno." In Investigationes Theologicocanonicae. Edited by U. Navarrete, 115-42. Rome: Università Gregoriana Editrice, 1978.

Delgado, Iva. "Manuel Fernandes Vila Real, polemista da Restauração." Revista da Biblioteca Nacional 3 (1983): 27-46.

Delgado, João Pinto. Poema de la Reina Ester, Lamentaciones del Propheta Ieremias, Historia de Rut, y varias poesias. Rouen: chez David du Petit Val, imprimeur ordinaire du Roy, 1627.

Díez, J. Ignacio, and Carsten Wilke, eds. Antonio Enríquez Gómez. Un poeta entre santos y judaizantes. Kassel: Eva Reichenberger, 2015.

Domínguez Ortíz, Antonio. "Una obra desconocida de Adam de la Parra." Revista bibliográfica y documental 5 (1951): 97-115.

Du Plessis Cardinal duc de Richelieu, Armand-Jean. Oeuvres théologiques, tome II. Traité qui contient la méthode la plus facile et la plus assure pour convertir ceux qui se sont séparés de l'Église. Edited by Stéphane-Marie Morgain and Françoise Hildesheimer. Paris: Honoré Champion, 2005.

Elliott, John H. Richelieu and Olivares. Cambridge: Cambridge University Press, 1991.

Elliott, John H. The Count-Duke of Olivares. The Statesman in an Age of Decline. New Haven and London: Yale University Press, 1986.

Elliott, John H., and Laurence W.B. Brockliss, eds. The World of the Favorite. New Haven and London: Yale University Press, 1999. 
Enríquez Gómez, Antonio. La Inquisición de Lucifer y visita de todos los diablos. Critical Edition, Study and Notes by Constance Hubbard Rose and Maxim P.A.M. Kerkhof. Amsterdam-Atlanta, GA: Rodopi, 1982.

Enríquez Gómez, Antonio. Luis dado de Dios a Luisy Ana Samuel dado de Dios a Elcana y Ana. Paris: René Baudry, 1645 .

Enríquez Gómez, Antonio. Política angélica, primera parte dividida en 5. Dialogos. Rouen: L. Maurry, 1647.

Frattarelli Fischer, Lucia. Vivere fuori dal ghetto. Ebrei a Pisa e Livorno (secolo XVIXVIII). Turin: Silvio Zamorani Editore, 2008.

Galbarro García, Jaime. El 'Triumpho lusitano’ de Antonio Enríquez Gómez. Seville: Editoral Universidad de Sevilla, 2015.

Galbarro García, Jaime. “Manuel Fernández Villareal y la propaganda de la 'nação’ Portuguesa." Versants 60 (2013): 131-42.

Gambin, Felice. "Es doblar el vivir': La Política angelica entre escritura divina y satánica." In Antonio Enríquez Gómez. Un poeta entre santos y judaizantes. Edited by J. Ignacio Dìez and Carsten Wilke, 138-6o. Kassel: Eva Reichenberger, 2015.

Gendreau-Massaloux, Michèle, and Constance H. Rose. “António Enríquez Gómez et Manuel Fernandes de Villareal: deux destins parallèles, une vision politique commune." Revue des études juives 136 (1977): 368-87.

Gomes, João Pedro da Silva. “O 'Epítome genealógico' de M. Fernandes Vila Real e a 'Política angélica' de Antonio Enríquez Gómez: o pensamento político de dois cristãos-novos na década de 1640." Master's thesis, Universidade Nova de Lisboa, 2008.

Graizbord, David L. Souls in Dispute. Converso Identities in Iberia and the Jewish Diaspora, 1580-170o. Philadelphia: Pennsylvania University Press, 2004.

HaCohen, Ruth, and Yaron Ezrahi. Composing Power, Singing Freedom: Overt and Covert Links between Music and Politics in the West. Tel Aviv: Van Leer Institute PressHakibbutz Hameuchad Publishing House, 2017. [Hebrew.]

Henshall, Nicholas. The Myth of Absolutism: Change and Continuity in Early Modern European Monarchy. London: Longman, 1992.

Hildesheimer, Françoise. "Une créature de Richelieu: Alphonse Lopez, le 'Seigneur Hebreo'." In Les Juifs au regard de l'histoire. Mélanges en l'honneur de Bernhard Blumenkranz. Edited by Gilbert Dahan, 293-99. Paris: Picard, 1985.

Jordan, William Chester. The French Monarchy and the Jews: From Philip Augustus to the Last Capetians. Philadelphia: Pennsylvania University Press, 1989.

Jouhaud, Christian. "Religion and politics in France during the period of the Edict of Nantes." In Religious Differences in France: Past and Present. Edited by Kathleen P. Long, 73-9o. Kirksville, MO: Truman State University Press, 2006.

Kaplan, Benjamin J. Divided by Faith: Religious Conflict and the Practice of Toleration in Early Modern Europe. Cambridge, MA: Belknap Press of Harvard, 2007. 
Kaplan, Yosef. "Between Calvinists and Jews in Seventeenth-Century Amsterdam." In Conflict and Religious Conversation in Latin Christendom: Studies in Honor of Ora Limor. Edited by Ram Ben-Shalom and Israel J. Yuval, 289-9o. Brepols: Turnhout, 2014.

Kaplan, Yosef. "Wayward New Christians and Stubborn New Jews: The Shaping of a Jewish Identity." Jewish History 8 (1994): 27-41.

Kerkhof, Maximiliaan Paul Adriaan Maria. "La 'Ynquisiçion de Luzifer y uisita de todos los diablos.' Texto desconocido de Antonio Enríquez Gómez: edición de unos fragmentos." Sefarad 38 (1978): 319-31.

Kramer-Hellinx, Nechama. Antonio Enríquez Gómez: literatura y sociedad en El siglo pitagórico y Vida de don Gregorio Guadaña. New York: Peter Lang, 1992.

Kuttner, Stephan, "Ecclesia de occultis non iudicat. Problemata ex doctrina poenali decretistarum et decretalistarum a Gratiano usque ad Gregorium PP. IX." In Acta congressus iuridici internationalis, Romae 1934 - 3: 225-46. Rome: Libr. Pont. Institutis Utriusque Iuris, 1936.

La Mothe Le Vayer, François de. Dialogues faits à l'imitation des Anciens. Edited by Bruno Roche. Paris: Honoré Champion, 2015.

La Mothe Le Vayer, François de. Oeuvres de François de La Mothe Le Vayer. Tome 2. Paris: Louis Billaine, 1669 .

Leroy, Béatrice, ed. Les édits d'expulsion des juifs; 1394, 1492, 1496, 1501. Biarritz: Atlantica, 1998.

Lipsio, Giusto. La Constanza. Edited by Domenico Taranto. Naples: Bibliopolis, 2004.

Lipsius, Justus. Politica: Six Books of Politics or Political Instruction. Edited by Jan Waszink. Assen: Van Gorcum, 2004.

López-Salazar Codes, Ana Isabel. “'Che si riduca al modo di procedere di Castiglia.' El debate sobre el procedimiento de inquisitorial portugués en tiempos de los Austrias." Hispania Sacra 59 (2007): 243-68.

López-Salazar Codes, Ana Isabel. “Puderão mais os inquisidores que o rey.' Las relaciones entre el Santo Oficio y la Corona en el Portugal de la Restauración (1640-1668).” Cuadernos de Historia Moderna 39 (2014): 137-63.

López Belinchón, Bernardo J. “'Sacar la sustancia al reino,' Comercio, contrabando y conversos portugueses, 1621-1640." Hispania 61 (2001): 1017-50.

Luria, Keith T. Sacred Boundaries. Religious Co-existence and Conflict in Early Modern France. Washington, DC: The Catholic University of America Press, 2005.

Lynn, Kimberly. Between the Court and the Confessional. The Politics of Spanish Inquisitors. Cambridge: Cambridge University Press, 2013.

Malvezzi, Virgilio. Il Ritrato del Privato Politico Cristiano. Edited by Maria Luisa Doglio. Palermo: Sellerio editore, 1993.

Marcocci, Giuseppe and José Pedro Paiva. História da Inquisição Portuguesa, 1536-1821. Lisbon: A esfera dos livros, 2013. 
Martínez de Bujanda, Jesús. El Índice de Libros Prohibidos y Expurgados de la Inquisición Española (1551-1819): evolución y contenido. Madrid: Biblioteca de Autores Cristianos, 2016.

McGaha, Michael. "Antonio Enríquez Gómez and the Count-Duke of Olivares." Texto y espectáculo: nuevas dimensiones críticas de la "comedia." Edited by Arturo PérezPisonero and Ana Semidey, 47-54. El Paso: University of Texas, 1990.

McGaha, Michael. "Divine Absolutism vs. Angelical Constitutionalism: The Political Theories of Quevedo and Enríquez Gómez." In Studies in Honor of Bruce W. Wardropper. Edited by Dian Fox, Harry Sieber and Robert Ter Horst, 181-92. Newark, DE: Juan de la Cuesta, 1989.

Mea, Elvira Cunha de Azevedo. A Inquisição de Coimbra no século XVI: a Instituição, os Homens e a Sociedade. Porto: Fundação Engenheiro António de Almeida, 1997.

Méchoulan, Henry. "L'Espagne dans le miroir des textes français." In L'Etat baroque. Textes réunis sous la direction d'Henry Méchoulan, étude préliminaire d'Emmanuel Le Roy Ladurie, préface de André Robinet, 421-46. Paris: Librairie philosophique J. Vrin, 1985 .

Méchoulan, Henry. "Manuel Fernandes Vila Real, un marrane en politique." Nova Renascença 67 (1998): 305-16.

Monter, William. Judging the French Reformation: Heresy Trials by Sixteenth-Century Parliaments. Cambridge, MA: Harvard University Press, 1999.

Muchnik, Natalia. “Antonio Vieira y la diaspora sefardí en el siglo XVII." In António Vieira, Roma e o universalismo das monarquias portuguesa e espanhola. Edited by Pedro Cardim and Gaetano Sabatini, 97-119. Lisbon: Centro de História de Além-Mar, 2011.

Muchnik, Natalia. "Du catholicisme des judéoconvers: Rouen, 1633." XVIIe siècle 231 (2006): 321-43.

Muchnik, Natalia. "Du judaïsme au catholicisme: les aléas de la foi au XVII e siècle." Revue Historique 623 (2002): 571-609.

Nahon, Gérard. “D’un singulier désir à la Loi du Dieu d'Israël: les nouveaux-chrétiens portugais en France XVI - XVIII e siècles." Arquivos do Centro Cultural Calouste Gulbenkian 48 (2004): 73-102.

Nahon, Gérard. "Exception française et réponse au modèle ibérique: Marie de Médicis et la 'Déclaration qui expulse les Juifs du Royaume de France' du 23 avril 1615." In L'expulsion des Juifs de Provence et de l'Europe méditerranéenne ( $X V^{e}-X V I^{e}$ siècles); exils et conversions. Edited by Danièle Iancu-Agou, 111-28. Paris and Leuven: Peeters, 2005 .

Nahon, Gérard. "From New Christians to the Portuguese Jewish Nation in France." In Moreshet Sepharad; The Sephardi Legacy. Edited by Haim Beinart, 2: 336-364. 2 vols. Jerusalem: Magnes Press and The Hebrew University, 1992. 
Nahon, Gérard. "Le modèle français du marranisme: perspectives nouvelles." In Inquisição; ensaios sobre mentalidade, heresias e arte. Edited by Anita Novinsky and Maria Luiza Tucci Carneiro, 227-65. Rio de Janeiro: Expressão e Cultura, 1992.

Nahon, Gérard. Les “Nations” Juives Portugaises du sud-ouest de la France (1684-1791). Documents. Paris: Fundação Calouste Gulbenkian-Centro Cultural Português, 1981.

Nahon, Gérard. "Prospective des 'Portugais' du sud-ouest de la France à la veille de la Révolution." In Politique et religion dans le judä̈me moderne, des communautés à l'émancipation. Edited by Daniel Tollet, 85-104. Paris: Presses de l'Université de Paris-Sorbonne, 1987.

Nahon, Gérard. "The Sephardim of France." In The Sephardi Heritage; Essays on the History and Cultural Contribution of the Jews of Spain and Portugal. Edited by R.D. Barnett and W.M. Schwab, 2: 46-74. 2 vols. Grendon, Northamptonshire: Gibraltar Books, 1989 .

Nider, Valentina. “La doppia simulazione di Enríquez Gómez: 'La culpa del primer peregrino'." In Alle radici dell'Europa. Mori, guide e zingari del mediterraneo occidentale. Vol. 2. Secoli XVII-XIX. Edited by Felice Gambin, 195-210. Florence: Seid, 2010.

Oelman, Timothy. "The Religious Views of Antonio Enríquez Gómez: Profile of a Marrano." Bulletin of Hispanic Studies 41 (1983): 201-9.

Pastore, Stefania. "A proposito di Matteo 18, 15: 'Correctio fraterna' e Inquisizione nella Spagna del Cinquecento." Rivista Storica Italiana 113 (2001):323-68.

Pastore, Stefania. Il Vangelo e la spada. L'Inquisizione di Castiglia e i suoi critici (14601598). Rome: Edizioni di Storia e Letteratura, 2003.

Pintard, René. Le Libertinage érudit dans la première moitié du XVII ème siècle. Nouvelle édition augmentée d'un avant-propos et de notes et réflexions sur les problèmes de l'histoire du libertinage. Geneva and Paris: Slatkine, 1983.

Powis, Jonathan. "Gallican Liberties and the Politics of Later Sixteenth-Century France." The Historical Journal 26 (1983): 515-30.

Prestage, Edgar. The Diplomatic Relations of Portugal with France, England and Holland from 1640 to 1668 . Watford: Voss \& Michael, 1925.

Prestwich, Menna. "The Huguenots under Richelieu and Mazarin 1629-1661: A Golden Age?" In Huguenots in Britain and their French Background 1550-1800. 75-197. Basingstoke: Macmillan, 1987 .

Prodi, Paolo. Una storia della giustizia. Dal pluralismo dei fori al moderno dualismo tra coscienza e diritto. Bologna: Il Mulino, 2000.

Prosperi, Adriano. Tribunali della coscienza: Inquisitori, confessori, missionary. Turin: Einaudi, 1996.

Pulido Serrano, Juan Ignacio. "The Unexecuted Plans for the Eradication of Jewish Heresy in the Hispanic Monarchy and the Example of the Moriscos: The Thwarted 
Expulsion of the Judeoconversos." In The Expulsion of the Moriscos from Spain: A Mediterranean Diaspora. Edited by Mercedes García Arenal and Gerard Wiegers, 179-96. Leiden and Boston: Brill, 2014.

Ramírez, Alejandro. Epistolario de Justo Lipsio y los Españoles (1577-1606). Madrid: Castalia, 1966.

Reinhardt, Nicole. Voices of Conscience: Royal Confessors and Political Counsel in Seventeenth-Century Spain and France. Oxford: Oxford University Press, 2016.

Révah, Israël Salvator. Antonio Enríquez Gómez, un écrivain marrane (v. 16oo-1663).

Edited by Carsten L. Wilke. Paris: Chandeigne, 2003.

Révah, Israël Salvator. "Autobiographie d'un marrane. Édition partielle d'un manuscript de João (Moseh) Pinto Delgado." Révue des Études Juives 119 (1961): 41-130.

Révah, Israël Salvator. "Aux origines de la rupture spinozienne: nouvel examen des origines du déroulement et des consequences de l'affaire Spinoza-Prado-Ribera." Annuaire du Collège de France, 71 (1971): 574-89.

Révah, Israël Salvator. Le Cardinal de Richelieu et la restauration du Portugal. Lisbon: Institut Français du Portugal, 1950.

Révah, Israël Salvator. "Les Jésuites portugais contre l'Inquisition: la campagne pour la création de la Compagnie Générale du Commerce du Brésil.," In Etudes portugaises. Edited by Charles Amiel, 155-83. Paris: Centre Calouste Gulbenkian, 1975.

Révah, Israël Salvator. "Manuel Fernandes Vilareal, adversaire et victime de l'Inquisition portugaise." Ibérida 1 (1959-1960): 33-54, 181-207.

Révah, Israël Salvator. "Un pamphlet contre l'Inquisition. La seconde partie de 'La política angélica' de Antonio Enríquez Gómez (Rouen, 1649).” Revue des Études Juives 121 (1962): 81-168.

Rose, Constance H. “Dios hará inquisición de vuestros juicios': Antonio Enríquez Gómez' Search for Justice.” Sefarad 61 (2001): 169-86.

Rose, Constance H. "Fiel a la antigua ley: 'La política angélica' de Enríquez Gómez." In Antonio Enríquez Gómez. Edited by Gema Ortega, 105-10. Cuenca: Diputación de Cuenca, departamento de cultura, 1996.

Rose, Constance H. "Portuguese Diplomacy Plays a Role in the Printing of Some Peninsular Works in Rouen in the Seventeenth Century." Archivos do Centro Cultural Português 9 (1975): 523-41.

Saavedra y Fajardo, Diego de. Empresas políticas. Edited by Sagrario López Poza. Madrid: Cátedra, 1999.

Salomon, Herman P. "Nova luz sobre a condenação à fogueira a Manuel Fernandes Vila Real (1. XII. 1652)." In Inquisição. Edited by Maria Helena Carvalho dos Santos, 2: 765-73. 3 vols. Lisbon: Universitária Editora, 1989.

Salomon, Herman P. “Was Antonio Enríquez Gómez (1600-1663) a Crypto-Jew?” Bulletin of Hispanic Studies 88 (2011): 397-421. 
Saraiva, António José. The Marrano Factory: The Portuguese Inquisition and Its New Christians, 1536-1765. Translated, revised and augmented by H.P. Salomon and I.S.D. Sassoon. Leiden: Brill, 2001.

Schaub, Jean-Frédéric. La France espagnole. Les racines hispaniques de l'absolutisme français. Paris: Éditions du Seuil, 2003.

Shaw, Leslie M.E. Trade, Inquisition and the English Nation in Portugal. Manchester: Carcanet, 1989 .

Solis, Duarte Gomes, Discursos sobre los comercios de las dos Indias. Edited by Moses Bensabat Amzalak. Lisbon: Gráfica Lisbonense, 1943.

Southerland, Nicola Mary. Princes, Politics, and Religion, 1547-1589. London: The Hambledon Press, 1984.

Stuczynski, Claude B. “A 'Marrano Religion'? The Religious Behavior of the New Christians of Bragança Convicted by the Coimbra Inquisition in the Sixteenth Century (1541-1605)." [Hebrew] 2 vols. PhD diss. Ramat-Gan: Bar-Ilan University, 2005.

Stuczynski, Claude B. "Converso Paulinism and Residual Jewishness: Conversion from Judaism to Christianity as a Theological-Political Problem." In Bastards and Believers: Converts and Conversion between Judaism and Christianity. Edited by Pawel Maciejko and Theodore Dunkelgrün. Philadelphia: University of Pennsylvania Press, forthcoming.

Stuczynski, Claude B. "Harmonizing Identities: The Problem of Integration of the Portuguese Conversos in Early Modern Iberian Corporate Politics." Jewish History 25 (2011): 229-57.

Stuczynski, Claude B. “Judaïcité et richesse dans l'apologétique des Conversos portugais: un argument contre-culturel." Atalaya 14 (2014): http://atalaya.revues.org/1295.

Stuczynski, Claude B. "Portuguese Conversos and the Manueline Imperial Idea: A Preliminary Study." Anais de História de Além-Mar 14 (2013): 45-61.

Szajkowski, Zosa. "An Auto-da-Fé against the Jews of Toulouse in 1685." The Jewish Quarterly Review 49 (1959): 278-81.

Tallon, Alain. "Inquisition romaine et monarchie française au XVI è siècle." In Inquisition et pouvoir. Edited by Gabriel Audisio, 311-24. Aix-en-Provence: Publications de l'Université de Provence, 2004.

Taranto, Domenico. Pirronismo e assolutismo nella Francia del'6oo. Studi sul pensiero politico dello scetticismo da Montaigne a Bayle (1580-1697). Milan: Franco Angeli, 1994. Thuau, Etienne. Raison d'État et pensée politique à l'époque de Richelieu. Paris: Armand Colin, 1966.

Torgal, Luís Reis. “A literatura 'marrânica' e as 'edições duplas' em Antonio Henriques Gomes (1600-1663)." Biblos 55 (1979): 197-228.

Torgal, Luís Reis. Ideologia política e teoria do Estado na Restauração: contributo para o seu estudo. 2 vols. Coimbra: Biblioteca Geral da Universidade de Coimbra, 1981-1982. 
Tuck, Richard. The Sleeping Sovereign: The Invention of Modern Democracy. New York: Cambridge University Press, 2015.

Tutino, Stefania. Shadows of Doubt: Language and Truth in Post-Reformation Catholic Culture. New York: Oxford University Press, 2014.

Vieira, António. Escritos sobre os Judeus e a Inquisição. Edited by José Eduardo Franco and Pedro Calafate. Lisbon: Temas e Debates, 2015.

Vilareal, Manuel Fernandes. Epítome genealógico del eminentissimo Cardenal Duque de Richelieu y discursos politicos sobre algunas acciones de su vida. Pamplona: Iuan Antonio Berdun, 1641.

Vilareal, Manuel Fernandes. Epítome Genealógico do Eminetissimo Cardeal Duque de Richelieu e Discursos Políticos sobre Algumas Acçõesa da Sua Vida. Edited by Antònio Borges Coelho. Lisbon: Caminho: 2005.

Warshawsky, Mathew. “A Spanish Converso's Quest for Justice: The Life and Dream Fiction of Antonio Enriquez Gómez." Shofar 23 (2005): 1-24.

Weiss, Nethanël. La Chambre ardente: Étude sur la liberté de conscience en France sous François Ier et Henri II (1540-1550), suivie d'environ 500 arrêts inédits rendus par le Parlement de Paris de mai 1547 à mars 1550. Geneva: Slatkine Reprints, 1970.

Wilke, Carsten L. Jüdisch-Christliches Doppelleben im Barock. Frankfurt: Peter Lang, 1994.

Wilke, Carsten L. "Manuel Fernandes Vila Real at the Portuguese Embassy in Paris, 1644-1649: New Documents and Insights." Journal of Levantine Studies 6 (2016): $153^{-76}$.

Wilke, Carsten L. "Un judaïsme clandestin dans la France du XVII e siècle: un rite au rythme de l'imprimerie." In Transmission et passages en monde juif. Edited by Esther Benbassa, 281-311. Paris: Publisud, 1997.

Zink, Anne. "Bayonne arrivées at départs au XVIIe siècle." In 1492, L'expulsion des Juifs d'Espagne. Edited by Roland Goetschel, 37-47. Paris: Maisonneuve et Larose, 1996.

Zink, Anne. "Une niche juridique: l'installation des Juifs à Saint-Esprit-lès-Bayonne au XVII e siècle." Annales - Histoire, Sciences Sociales 49 (1994): 639-69. 